\title{
Identification and Developmental Expression of a Novel Low Molecular Weight Neuronal Intermediate Filament Protein Expressed in Xenopus laevis
}

\author{
Lawrence R. Charnas, ${ }^{1,2}$ Ben G. Szaro, ${ }^{2, a}$ and Harold Gainer ${ }^{2}$ \\ 'Unit on Neurogenetics, Human Genetics Branch, NICHD, and 'Laboratory of Neurochemistry, NINDS, National Institutes \\ of Health, Bethesda, Maryland 20892
}

\begin{abstract}
Xenopus laevis is a valuable model system for the study of vertebrate neuroembryogenesis. However, very few wellcharacterized nervous system-specific molecular markers are available for studies in this organism. We screened a $X$. laevis adult brain cDNA library using a CDNA probe for mouse low molecular weight neurofilament protein (NF-L) in order to identify neuron-specific intermediate filament proteins. Clones for two distinct neuron-specific intermediate filament proteins were isolated and sequenced. One of these encoded for a Xenopus NF-L (XNF-L) and the other for a novel neuron-specific Xenopus intermediate filament protein (XNIF) that was present earlier and more abundantly than XNF-L during development.
\end{abstract}

XNIF contained a central rod domain with multiple sequence features characteristic of IF proteins. The XNF-L was very similar to mouse NF-L, with a $77 \%$ sequence identity in the rod domain and the presence of a polyglutamic acid region in the tail domain, characteristic of type IV neurofilament proteins. In contrast, XNIF showed only $60 \%$ identity to mouse NF-L in the rod domain and lacked the glutamic acid-rich sequence in the tail domain. XNIF also had a very low $(\sim 38 \%)$ sequence identity in the head and tail domains as compared to NF-L and other neurofilament proteins (45\% identity to the head domain of $\alpha$-internexin).

In the adult frog, XNIF mRNA is detected by Northern blots only within the nervous system and by in situ hybridization histochemistry exclusively in neurons, particularly in the medullary reticular system and spinal cord. Antisera raised against the unique tail region of XNIF detected a single distinct $60 \mathrm{kDa}$ band in Western blots of nervous system cytoskeletal preparations, and this XNIF immunoreactivity was concentrated in axons in the PNS and in small perikarya in the dorsal root ganglion. In contrast, NF-L immunoreactivity was principally in the large perikarya in the dorsal root ganglion. In development, XNIF mRNA appears more abundant than XNF-L mRNA in all premetamorphic stages examined. XNIF mRNA is first detectable at stage 24 (26 hr), whereas

\footnotetext{
Received Dec. 16, 1991; revised Feb. 25, 1992; accepted Mar. 10, 1992.

We thank Drs. Thomas Sargent, George Michaels, and Igor Dawid for their help in the initial cloning experiments, Dr. Klaus Richter for the use of his library, and Dr. James Battey for support and encouragement.

Correspondence should be addressed to Lawrence R. Charnas, Building 10 Room 9S242, National Institutes of Health, 9000 Rockville Pike, Bethesda, MD 20892.

"Present address: Department of Biological Sciences, SUNY at Albany, 1400 Washington Avenue, Albany, NY 12222.

Copyright (C) 1992 Society for Neuroscience $0270-6474 / 92 / 123010-15 \$ 05.00 / 0$
}

stable expression of XNF-L is at stage 35/36 (50 hr). XNIF immunoreactivity is detectable within the cement gland, within many neuronal cell bodies and axon tracts within the developing nervous system, and within all cellular layers of the developing retina. The availability of these two distinct neuron-specific intermediate filament proteins, with different temporal and spatial expression patterns, should provide new markers as well as targets for functional perturbation in the developing $X$. laevis nervous system.

In the vertebrate nervous system, the neuronal intermediate filament (neurofilament) proteins are derived from distinct genes and are expressed in a highly selective manner during development as a function of neuronal type and stage of differentiation. Xenopus laevis is an important biological model for early neural development because of the accessibility and rapid development of its embryonic nervous system. For example, cDNA probes to a Xenopus peripherin-like protein, a type III neurofilament protein originally identified in mammals (Parysek and Goldman, 1988; Thompson and Ziff, 1989), have been used to study factors affecting neural induction in Xenopus (Sharpe et al., 1989). Recently, purified monoclonal antibodies directed against the $X$. laevis type IV middle molecular weight neurofilament protein (XNF-M) were injected into single blastomeres of a two cell embryo and were shown to inhibit specifically axonal development in neurons descended from the injected blastomere (Szaro et al., 1991a). With more identifications of neurofilament proteins of developing neurons in $X$. laevis, it will be possible to develop specific cDNA probes and antibodies directed against them and use these as tools for studying various aspects of neuronal differentiation.

Further identification and characterizations of neurofilament proteins are necessary in Xenopus because previous studies have shown that neural intermediate filament proteins in lower vertebrates are quite heterogeneous (Quitschke and Schechter, 1984; Quitschke et al., 1985; Godsave et al., 1986; Szaro and Gainer, $1988 \mathrm{a}, \mathrm{b})$. Previously, four neuronal intermediate filament proteins have been partially identified and characterized in $X$. laevis. Three were identified by antibody cross-reactivities with mammalian neurofilament proteins (Phillips et al., 1983; Szaro and Gainer, 1988a), and are comparable to the low (NF-L), middle (NF-M), and high (NF-H) molecular weight neurofilament triplet proteins of mammals. A partial cDNA clone with similarity to NF-M has been reported (Sharpe, 1988), and we report in this study the isolation of cDNA clones for Xenopus NF-L. The fourth neurofilament protein, which resembles mammalian pe- 
ripherin in its sequence (Sharpe et al., 1989), has been characterized as a cDNA clone. Of these four, Xenopus NF-M and peripherin have been detected in the nervous system at the time of earliest axonal outgrowth (Sharpe et al., 1989; Szaro et al., 1989). Peripherin was found preferentially expressed in the developing anterior nervous system (Sharpe et al., 1989), whereas NF-M immunoreactivity was detected in neuronal perikarya and axons throughout the developing nervous system (Szaro et al., 1989).

We report here the cDNA cloning and characterization of this fifth, novel Xenopus neurofilament protein, which differs from previously reported neurofilament protcins. Likc NF-M, XNIF (Xenopus neuron-specific intermediate filament protein) is found in axons of early differentiating neurons throughout the nervous system. Given this information, XNIF can now serve as an additional marker for studies of neurofilament protein expression and neuronal differentiation and as a further target for functional studies of neurofilament proteins.

\section{Materials and Methods}

Screening of cDNA libraries. A partial-length cDNA (Lewis and Cowan, 1985 ) for the mouse 68,000 Da neurofilament protein (NF-L) was labeled with ${ }^{32} \mathbf{P}$ by random primed synthesis. At reduced stringency $[2 \times$ saline-sodium citrate $(\mathrm{SSC}), 65^{\circ} \mathrm{C}$, this probe hybridized on Northern blots of Xenopus laevis brain mRNA with bands at 2.5 kilobases $(\mathrm{kb})$ and $4.0 \mathrm{~kb}$. This probe was used at reduced stringency $\left(2 \times \mathrm{SSC}_{-}, 65^{\circ} \mathrm{C}\right)$ to screen 50,000 plaques from an amplified $\lambda \mathrm{gt} 11 \mathrm{cDNA}$ library made from polyA + RNA from brains of adult, wild-type $X$. laevis frogs (Richter et al., 1988). From this screening, five phage clones were obtained, including XNK3 and XNF21, representing two distinct mRNAs encoding separate proteins. Labeled cDNA insert fragments from these clones were used at higher stringency $\left(0.1 \times \mathrm{SSC}, 65^{\circ} \mathrm{C}\right)$ to obtain additional clones from this library, including the clone $10 \mathrm{a} 1$, which was obtained with probes made from XNK3.

To obtain additional cDNA clones encoding the missing $5^{\prime}$ end of the mRNA represented by XNF21, a separate cDNA library was prepared. This library was made from poly $A^{+}$RNA obtained from the brains of sibling, juvenile (2-3 months postmetamorphosis) periodic albino (Hoperskaya, 1975) $X$. laevis frogs. The details of construction of this random hexamer primed cDNA library in $\lambda g t 10$ were as described by Davis et al. (1986).

Sequencing and analysis of $c D N A$ clones. Sequencing was performed by the dideoxy method (Sanger et al., 1977) on nested delctions (Henikoff, 1984) and with synthetic oligonucleotide primers using a Sequenase 2.0 kit (U.S. Biochemicals, Cleveland, $\mathrm{OH}$ ) as described by the manufacturer. All sequences were performed in both directions. Nucleotide and amino acid sequences were analyzed using the computer programs of the University of Wisconsin Genetics Computer Group (Devereaux et al., 1985). Nucleotide sequences of other intermediate filament proteins were obtained for comparison from the GenBank data base (Los Alamos, NM).

Northern blot analysis. For analysis of mRNA expression in adults, polyA ${ }^{+}$RNA was prepared from adult $X$. laevis (Nasco, Ft. Atkinson, WI) brain, liver, muscle, skin, and ovary, and from $X$. laevis XTC cells (Pudney et al., 1973), a cell line derived from kidney. Aliquots of $1 \mu \mathrm{g}$ were separated on methylmercury denaturing $1.2 \%$ agarose gels (Bailey and Davidson, 1976) electroblotted to nylon membrane, hybridized to probes labeled with ${ }^{32} \mathrm{P}$ by random primed synthesis, and washed as described previously (Sargent et al., 1986).

Developmental expression was examined using total RNA made from laboratory-bred embryos [stages 10 (gastrula), 18 (neural tube), 24 (tailbud), 29/30 (mid larval), 35/36 (newly hatched tadpole), and 42 (early swimming tadpole) (Nieuwkoop and Faber, 1967)] and juvenile (2-3 month postmetamorphic) periodic albino $X$. laevis frogs as described previously (Davis et al., 1986). Aliquots of $10 \mu \mathrm{g}$ of RNA were loaded onto separate regions of the same $1 \%$ agarose/formaldehyde gel and transferred simultaneously to nitrocellulose filters by capillary blotting. Blots were hybridized overnight at $42^{\circ} \mathrm{C}$ with equivalent amounts of denatured cDNA probes labeled with ${ }^{32} \mathrm{P}$ by random primed synthesis ( $20 \mathrm{ml}$ of labeling solution at $5 \times 10^{5} \mathrm{cpm} / \mathrm{ml}$ ) as described previously
(Davis et al., 1986). The next day, blots were washed twice in $2 \times \mathrm{SSC}$, $0.1 \%$ SDS at room temperature, followed by a higher stringency wash at $60^{\circ} \mathrm{C}$ in $0.1 \times \mathrm{SSC}, 0.1 \% \mathrm{SDS}$. The blots were then exposed to $\mathrm{x}$-ray film for $7 \mathrm{~d}$.

In situ hybridization. Albino frogs (Nasco, Ft. Atkinson, WI) were anesthetized by immersion in $0.1 \%$ tricaine methane sulfonate, and then fixed by intraventricular perfusion of $4 \%$ paraformaldehyde, $0.1 \%$ tricaine methane sulfonate in frog Ringer's solution. After tissues had been dissected free and postfixed in 4\% paraformaldehyde in Ringer's, thcy were dehydrated and embedded in paraffin, and cut into $10-\mu \mathrm{m}$-thick sections. These sections were fixed to silanized slides according to the manufacturer's directions (Polysciences Inc., Warrington, PA). Production of ${ }^{35} \mathrm{~S}$-labeled cRNA probes from XNK3, preparation of tissue sections, slide hybridization, washing, dipping in NTB3 emulsion, exposure, and developing were as described previously (Zoeller et al., 1989).

Primary antibodies. To identify and localize the protein encoded by the XNK 3 cDNA clone, an antibody (anti-XNIF) was generated against a synthetic peptide (Peptide Technologies, Washington, DC) from the C-terminal domain of the predicted sequence of the Xenopus neuronal intermediate filament (XNIF) protein (amino acid sequence KTSKPGDQEKI). The synthetic peptide was conjugated with glutaraldehyde to several protein carriers and used to immunize rabbits for the production of antisera as described previously (Altstein et al., 1988). The antisera described in this article were derived from rabbit LC2.

Additional antibodies shown previously to recognize intermediate filament proteins in the nervous system of $X$. laevis (Szaro and Gainer, 1988a,b; Szaro et al., 1989) were used. The mouse monoclonal antibody aIFA is directed against an epitope common to nearly all intermediate filament proteins, which is located at the carboxyl end of the $\alpha$-helical rod domain (Pruss et al., 1981). Three additional mouse monoclonal antibodies made against cytoskeletal preparations of adult $X$. laevis nervous system (Szaro and Gainer, 1988a) recognize neurofilament proteins similar by molecular weight and antibody cross-reactivity criteria to mammalian NF-L (aXNF-L, hybridoma XC5D10), NF-M (aXNF-M, hybridoma XC10C6), and NF-H (aXNF-H, hybridoma XC9B10). Two additional antibodies that recognize intermediate filament proteins found in $X$. laevis glial cells were also employed. The first was a polyclonal antibody made in rabbit against hamster vimentin (rabbit 146 from $R$. Goldman, Northwestern University, Chicago, IL), which cross-reacts with a vimentin-like protein in $X$. laevis (Szaro and Gainer, 1988b). The second was a polyclonal antibody made in rabbit against human glial fibrillary acidic protein (aGFAP) (Raff et al., 1979). This antiserum has been shown to cross-react with two intermediate filament proteins of $X$. laevis glial cells (Szaro and Gainer, 1988b).

Western blots. Protein samples enriched for intermediate filament proteins were prepared from spinal cords, brains, and sciatic nerves of adult $X$. laevis frogs (Nasco, Ft. Atkinson, WI) as described previously (Szaro and Gainer, 1988a). An aliquot of $350 \mu \mathrm{g}$ of protein was loaded across the entire width $(12 \mathrm{~cm})$ of a $7.5 \%$ polyacrylamide slab gel, separated by SDS electrophoresis, and transferred electrophoretically onto nitrocellulose paper, which was cut into 3-5 $\mathrm{mm}$ strips and stained by antibodies using hydrogen peroxide and 4-chloro-1-naphthol as chromogen as previously described (Szaro and Gainer, 1988a,b). Anti-lFA, anti-XNF-L, anti-XNF-M, and anti-XNF-H were used as undiluted hybridoma supernatants. The anti-vimentin antiserum was diluted 1:500, and the aXNIF antiserum, 1:4000. Solutions of $10 \%$ normal serum, which was used in the preparation of supernatants and antisera dilutions, were used as controls. In addition, preimmune serum from the LC.2 rabbit, which made the aXNIF antiserum, was diluted to $1: 4000$ and used as an additional control for nonspecific staining by the anti-XNIF antiscrum.

Immunocytochemistry. For immunocytochemistry of postmetamorphic frogs (Nasco, Ft. Atkinson, WI; and Xenopus I, Ann Arbor, MI), animals were anesthetized by immersion in $0.1 \%$ tricaine methane sulfonate and the CNS and dorsal root ganglia removed. These were fixed by immersion in ice-cold methanol, dehydrated, and embedded in paraffin. After sectioning ( $15 \mu \mathrm{m}$ thick), ribbons were mounted onto slides and processed for immunoperoxidase histochemistry as described fully elsewhere (Whitnall et al., 1985; Szaro and Gainer, 1988a). Slides were developed in the presence of diaminobenzidine and nickel chloride using the glucose oxidase-catalyzed reaction with dextrose as the source of peroxide (Whitnall et al., 1985).

Periodic albino (Hoperskaya, 1975) embryos and tadpoles were bred in the laboratory via chorionic gonadotropin-induced natural spawnings 
A $\begin{array}{llllll}10 & 30 & 50 & 70 & 90 & 110\end{array}$ ACTCTCCTCCACTGTCCCAAACACACCT TGCAGCT TCAGCCATGACTTCCAGGGAGCTCTACACTTCGTCCTACAAGAGATCTTTGGGGATTCCCCTAGGTCCTCCAGCCTCCTGTATA

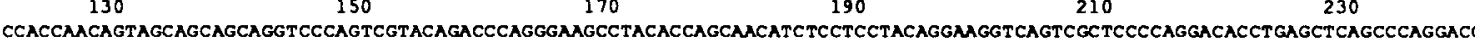

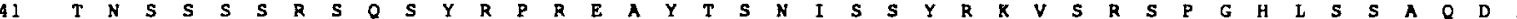

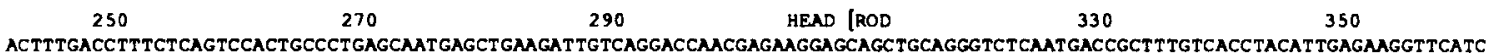

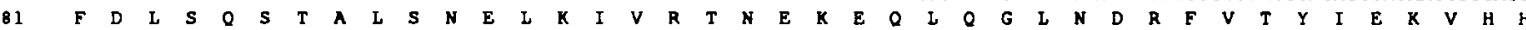
$\begin{array}{lllll}370 & 390 & 410 & 430 & 450\end{array}$ ACCTGGAGCAGCAGAACAMGCTGTTGGAGAGCGAGGTGACCTTGCTGAGCAMAGCACTCAGAGCCTTCCCGGCTGAGCCATATCTATGAGCAGGAGATCCGGGAGCTGAGGTCCAAGC

$\begin{array}{lllllllllllllllllllllllllllllllllllllllll}121 & L & E & Q & 0 & N & K & L & L & E & S & E & V & T & L & L & R & 0 & K & H & S & E & P & S & R & L & S & H & I & Y & E & Q & E & I & R & E & L & R & S & K & I\end{array}$

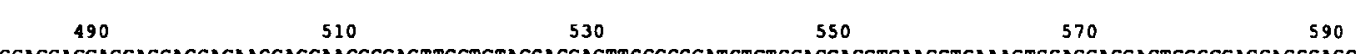

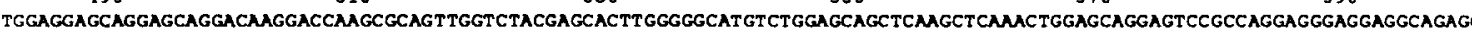

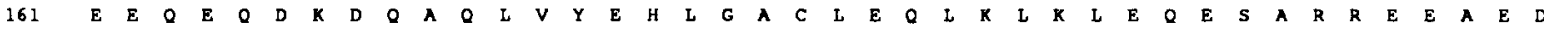
$\begin{array}{llllll}610 & 630 & 650 & 670 & 690 & 710\end{array}$ ATGTCATGAMGAACTATAGGAAGGACTTGGACCAAGCCACCCTCAACCGCTTGCAACTGGAGMAGAGGTGGAGTCGCTGCTGGACGAGATCGCTTTCCTGAGGAAATCCATGAGGAGC

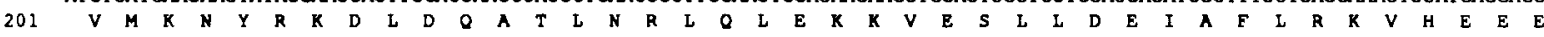
730075007700000 AGATTGCTGAGCTTCAGGCTTCCGTGCAGGAGGGCAGATCTCTGTGGAGATGGATGTGGTTAGCAAGCCCGATCTGACGGCTGCACTGAAGAAATCCGCATGCAGTACGAGGTTTGT

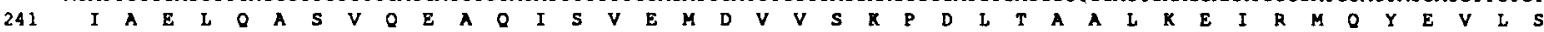
$850 \quad 870 \quad 890 \quad 910 \quad 930 \quad 950$ CTGCCCGCAATCAGCAGTCATCCGAGGAGTGGTACCAGGCCAMGATTGCCAACGTATCTCTGGAGCTTCCCGTAATAAGACTCTGTCCGTCAGGCCAAAGAGGAGATCACAGAGTACC

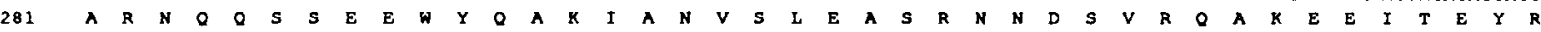

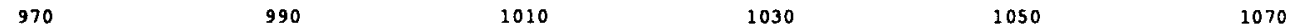
GCCGGCAGCTCCAGGCACGACATTGGAGATTGATGCTCTGCGCAGTGCCAACGATCCCTAGAGAGGCAGCTGCAGGMGCCGAGGATAGGAGTAATGAAGAATGTCTCATCTGCAGO

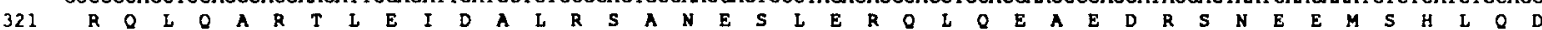

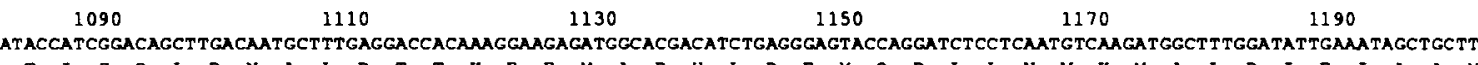

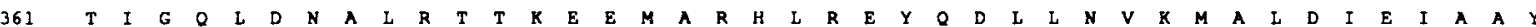
$1210 \quad 1230$ ROD] TAIL $1250 \quad 1270 \quad 1290 \quad 1310$ ACAGGAAA TCCTAGAAGGgAGgAGACACGTCTAACCTCAGTGGGCGGAGGCAGCATGTTCGgTATTGGCTACCCATACTCCTCTGGGTCATACTCCGGTGGCAGAGCTCCACCACAA

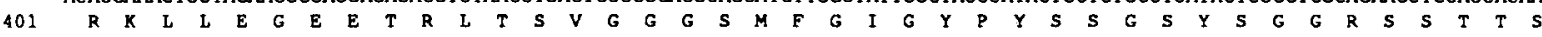
$\begin{array}{lllll}1330 & 1350 & 1370 & 1390 & 1410\end{array}$ GCACCATCAGTATCAGGAAAGAGGAGAMGAAGGAGTCACCAGAGGGTGGGAAAGGAGGTAGCTCTGGCCAACCCAAMACCTCAMAGCCAGGGGTCAAGMAAGATCTCACAMAAAGCTG

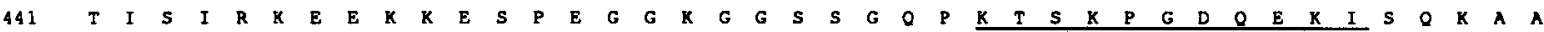
$\begin{array}{lllll}1450 & 1470 & 1490 & 1510 & 1530\end{array}$

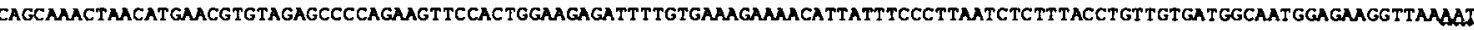
$181 \quad \mathrm{~A} N$

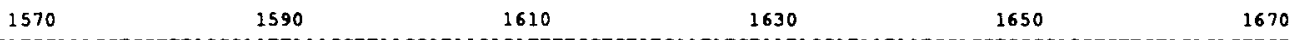
AAASTGATCCAMCCTGCTTTACCGMATTAMAGCTTAMCCATAACACATTTTGCTGTATGMTATCTMTAGGATATAMCCACGTGCCCAGCTGTTGTACACAGTTCTACAGGGGTC
1690
1710
1730
1750
1770
1790

TTACGATATCACTGGGCAMGCATAAGGGAGAAATAGCAAGACTCGCTGGTCCAGTTGMATAAGTCAACTATATGgTGAAGTTGTGTTTCTGTTGGCCAACAGATGGGCAAACATATCA $\begin{array}{ccccc}1810 & 1830 & 1850 & 1870 & 1890\end{array}$ TTAAGTTCCTTCCCTACCGACACT GCAGAATATCACAAACCAGCCATTCACAGgagatTAaTACTACACCATTATCATCCATATATT TCTATTACCTGTAGCTGAGGCCTTTGTCACTGC

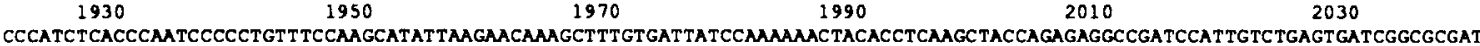

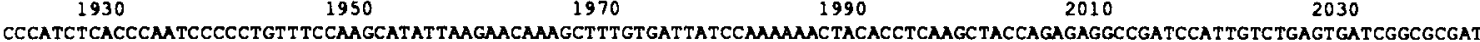

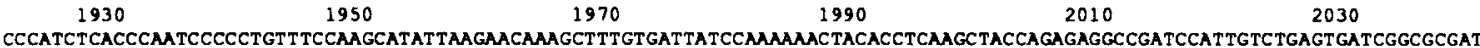

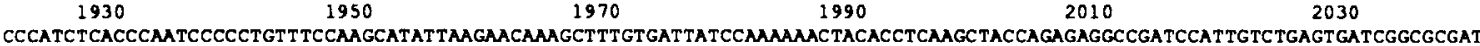

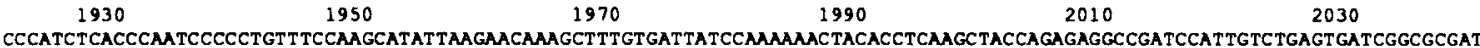

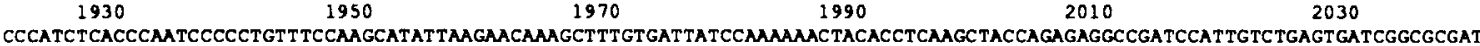

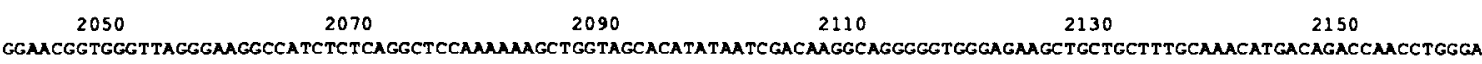

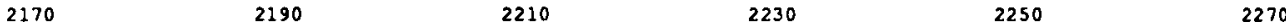

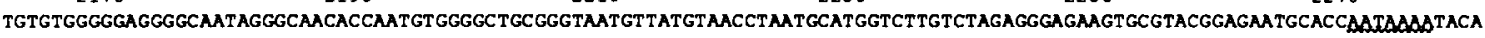
2290

ACTGTCTGTALAAAAAAA

$\mathrm{B}$

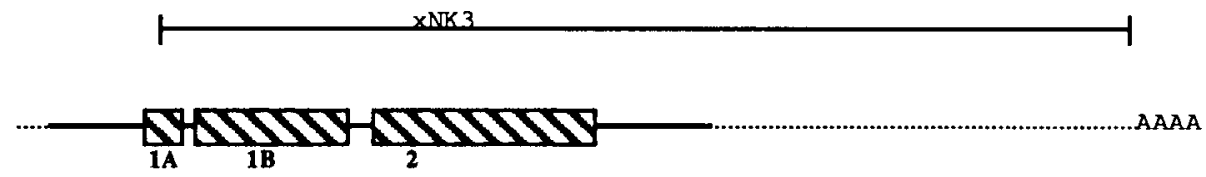

Figure 1. A, Nucleotide and predicted amino acid sequences of the Xenopus neuronal intermediate filament protein XNIF derived from cDNA clone $10 \mathrm{a} 1$. Translation was begun at the first in-phase methionine of the longest open reading frame. Nucleotide numbers are indicated above the 
(Gurdon, 1967), and then collected and staged (Nieuwkoop and Faber, 1967). Embryos and tadpoles were fixed by immersion in $25 \%$ dimethyl sulfoxide, $75 \%$ methanol and processed for peroxidase-based immunocytochemistry as whole-mounts (Dent et al., 1989) and modified as described previously (Szaro et al., 1991a). Immunostained preparations were examined first as whole-mounts. Selected specimens were then embedded in paraffin and sectioned as described previously (Szaro et al., 1991a). Primary antibody dilutions and controls for all procedures were as described for Western blotting.

\section{Results}

Identification and sequence analysis of clones encoding the Xenopus neuronal intermediate flament protein (XNIF)

Fifty thousand plaques of a $X$. laevis brain cDNA library in $\lambda$ gt 11 (Richter et al., 1988) were screened with a mouse NF-L cDNA probe (Lewis and Cowan, 1985) at reduced stringency. This led to the identification and purification of five phage clones. The clone with the longest insert [XNK3, 1.9 kilobase pairs $(\mathrm{kbp})$ ] was sequenced and found to contain a partial open reading frame. The brain cDNA library was subsequently rescreened using XNK 3 as a probe at high stringency, and a resultant 2.4 $\mathrm{kbp}$ clone ( $10 \mathrm{al})$ was isolated and sequenced. This second clone contained a single long open reading frame with an in-frame start ATG codon, a 50 bp 5' untranslated region, and a long 3' untranslated region ending with a polyadenylation tract. Two potential polyadenylation sequences (AATAAA) were identified, one of which closely preceded the observed polyA tract.

The complete nucleotide sequence of clone $10 \mathrm{a} 1$ and the amino acid sequence predicted by its open reading frame are presented in Figure $1 A$. The open reading frame predicted a 53,512 Da protein, which we have termed the XNIF protein (Xenopus neuronal intermediate filament protein). The XNIF protein had a predicted amino acid sequence containing features characteristic of intermediate filament proteins. These features included a central domain containing three regions $(1 \mathrm{~A}, 1 \mathrm{~B}, 2)$ of heptad repeats $(a h c d e f g)_{n}$, in which the first and fourth amino acids are nonpolar or uncharged at greater than $75 \%$ of the positions (Steinert and Parry, 1985). In the case of the XNIF protein, this number was $86 \%$. This central domain, termed the rod domain, had at its amino end the sequence LNDRF, and at its carboxyl end the sequence KLLEGEE. Closely related sequences are found at comparable positions in all other intermediate filament proteins (Steinert and Roop, 1988). Furthermore, the sequence KLLEGEE contains the epitope for the aIFA antibody, a monoclonal antibody specific for both vertebrate and invertebrate intermediate filament proteins (Pruss et al., 1981).

Comparison of the predicted amino acid sequence of XNIF to other intermediate filament proteins

Although the amino acid sequence of the XNIF protein clearly predicted an intermediate filament protein, it did not appear to represent any previously known intermediate filament protein,
Table 1. Amino acid identities between XNIF and various cytoplasmic intermediate filament proteins

\begin{tabular}{llll} 
Intermediate filament protein & $\begin{array}{l}\text { N-ter- } \\
\text { minal }\end{array}$ & Rod & $\begin{array}{l}\text { C-Ter- } \\
\text { minal }\end{array}$ \\
\hline Type III & & & \\
XNIF/Xenopus desmin & 38 & 54 & 17 \\
XNIF/Xenopus peripherin & 25 & 51 & 12 \\
XNIF/Xenopus vimentin & 29 & 53 & 19 \\
Xenopus desmin/hamster desmin & 70 & 85 & 84 \\
Xenopus vimentin/hamster vimentin & 57 & 84 & 71 \\
Xenopus peripherin/rat peripherin & 49 & 77 & 61 \\
Xenopus desmin/hamster vimentin & 43 & 71 & 40 \\
Type IV & & & \\
Xenopus NF-L/mouse NF-L & 65 & 78 & 60 \\
XNIF/Xenopus NF-L & 34 & 56 & 24 \\
XNIF/mouse NF-L & 38 & 60 & 38 \\
XNIF/rat $\alpha$-internexin & 45 & 62 & 35 \\
Mouse NF-L/rat $\alpha$-internexin & 37 & 58 & 31 \\
\hline Amo & & & \\
\hline
\end{tabular}

Amino acid sequences of the indicated domains of each IF protein were computer aligned and percentage identities were calculated using the GAP program in the University of Wisconsin's Genetics Computer Group package. The pairs of sequences used for each alignment comparison are separated by a slash. References: Rat peripherin (Leonard et al., 1988); Xenopus peripherin (Sharpe et al., 1989); Xenopus vimentin (Hermann et al., 1989a); hamster vimentin (Quax et al., 1983); hamster desmin (Quax et al., 1984); Xenopus desmin (Hermann et al., 1989b); rat $\alpha$-internexin (Fliegner et al., 1990); mouse NF-L, (Julien et al., 1986); XNIF and Xenopus NF-L, present results.

either neuronal or non-neuronal. Since the clones encoding the XNIF protein were originally identified with a cDNA probe from mouse NF-L, the most likely possibility was that the XNIF protein represented the $X$. laevis homolog to mammalian NF-L. A $X$. laevis NF-L was expected to exist based on work done with Bodian's silver stain (Phillips et al., 1983) and with antibodies (Szaro and Gainer, 1988a). However, the predicted molecular weight of XNIF ( $54 \mathrm{kDa}$ ) was much smaller than that expected for Xenopus NF-L (70 kDa by SDS-PAGE). Moreover, the predicted amino acid sequence of XNIF lacked other structural features characteristic of neurofilament proteins, such as a tail domain rich in glutamic acid residues. In addition, the percentage of identical amino acids at aligned positions between the XNIF protein and mouse NF-L was only $60 \%$ in the rod domain, and $38 \%$ in the head and tail domains (Table 1; see Fig. 3). Overall, this degree of identity between the XNIF protein and mouse NF-L, as well as that seen between XNIF and other representative intermediate filament proteins, was less than typically seen between Xenopus intermediate filament proteins and their mammalian equivalents (Table 1). Thus, based on these sequence criteria, we have considered the XNIF protein to represent a novel intermediate filament protein (see Discussion).

\footnotetext{
DNA sequence, and amino acid residue numbers are indicated at the ends of the translated sequence. The junctions betwcen head, rod, and tail domains are indicated with brackets. The amino acid sequence from the tail domain used to make the synthetic peptide to raise antisera is doubly underlined. Two potential polyadenylation sequences in the $3^{\prime}$ untranslated portion are indicated with dotted underlines. Not all adenosine residues present in the 3' end of the clone are included in this figure. The GenBank accession number for XNIF is M86653. B. Schematic drawing indicating relative sizes and overlap of the sequence information of clones 10a1 and XNK3. Both clones 10al and XNK3 encoded a single open reading frame that corresponded to an intermediate filament protein (bottom line). Predicted $5^{\prime}$ and $3^{\prime}$ untranslated regions of the cDNAs are indicated on the bottom line as dotted lines. The $\alpha$-helical segments $(I A, I B$, and 2$)$ of the rod domain of the predicted XNIF protein are shown as crosshatched bars, and the head, tail, and rod domain linker segments are depicted as solid lines. The polyadenylation sequence present in clone 10a 1 , but not $\mathrm{XNK} 3$, is indicated by $A A A A$.
} 


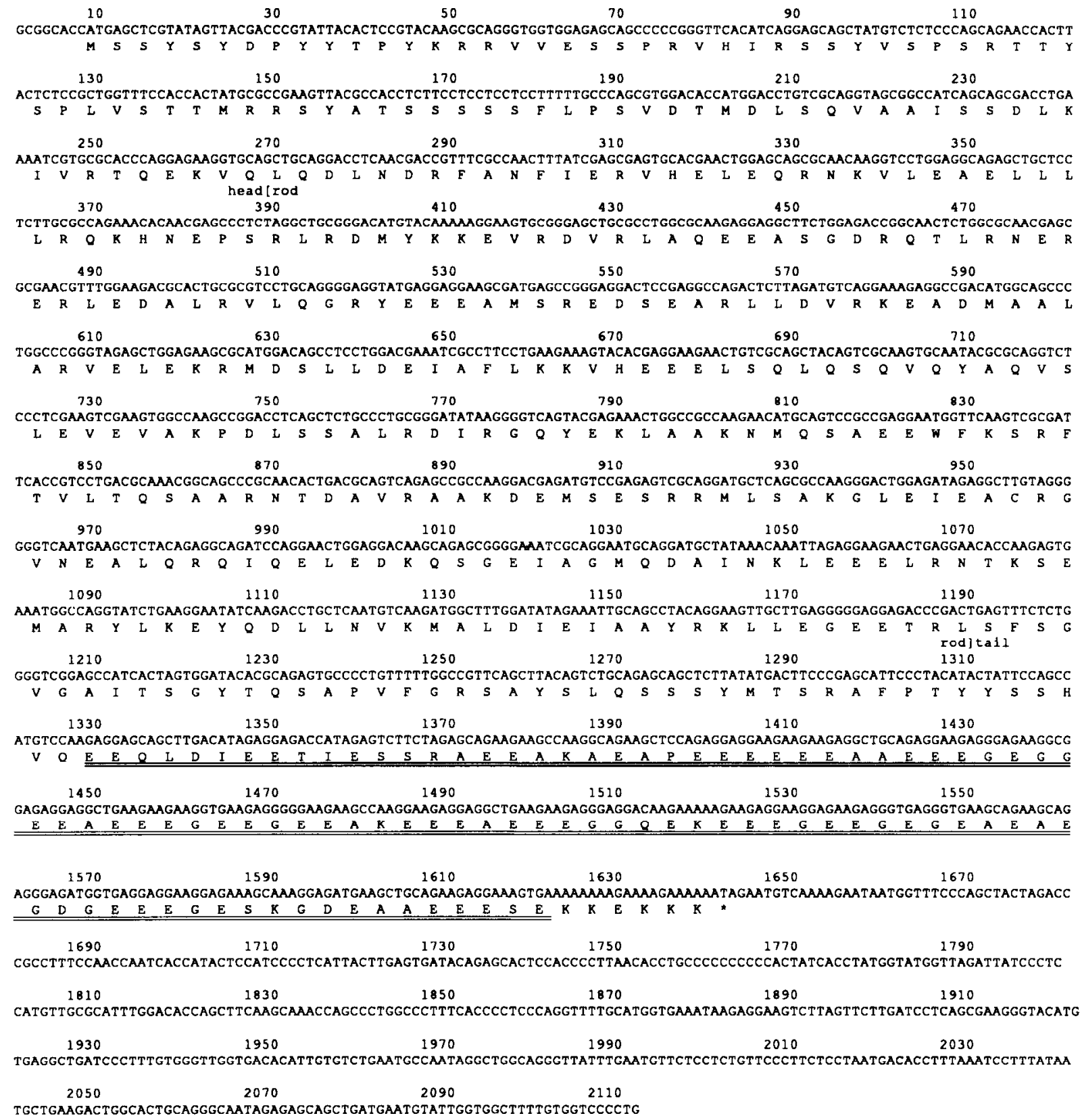

B

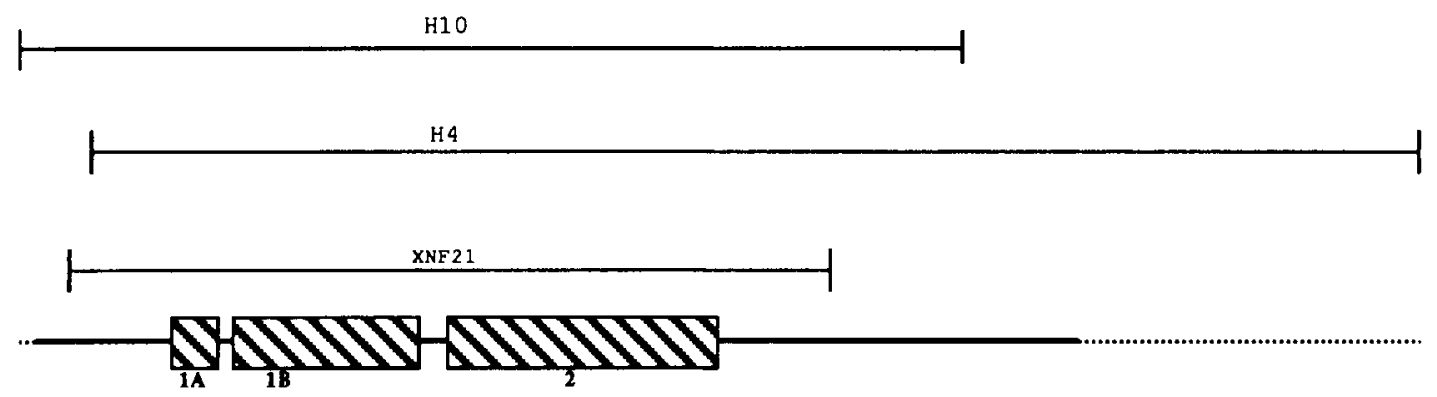

Figure 2. A, Assembled partial cDNA sequence and deduced amino acid sequence of XNF-L. The junctions between head, rod, and tail domains are indicated with brackets. The glutamic acid-rich portion of the tail domain is double underlined. The GenBank accession number for XNF-L is M86654. B. Schematic drawing indicating relative sizes and overlap of sequence information of clones $\mathrm{H} 4, \mathrm{H} 10$, and XNF21. The relative position of the assembled, predicted sequence of the XNF-L protein is shown on the bottom line. Other conventions are as in Figure $1 B$. 

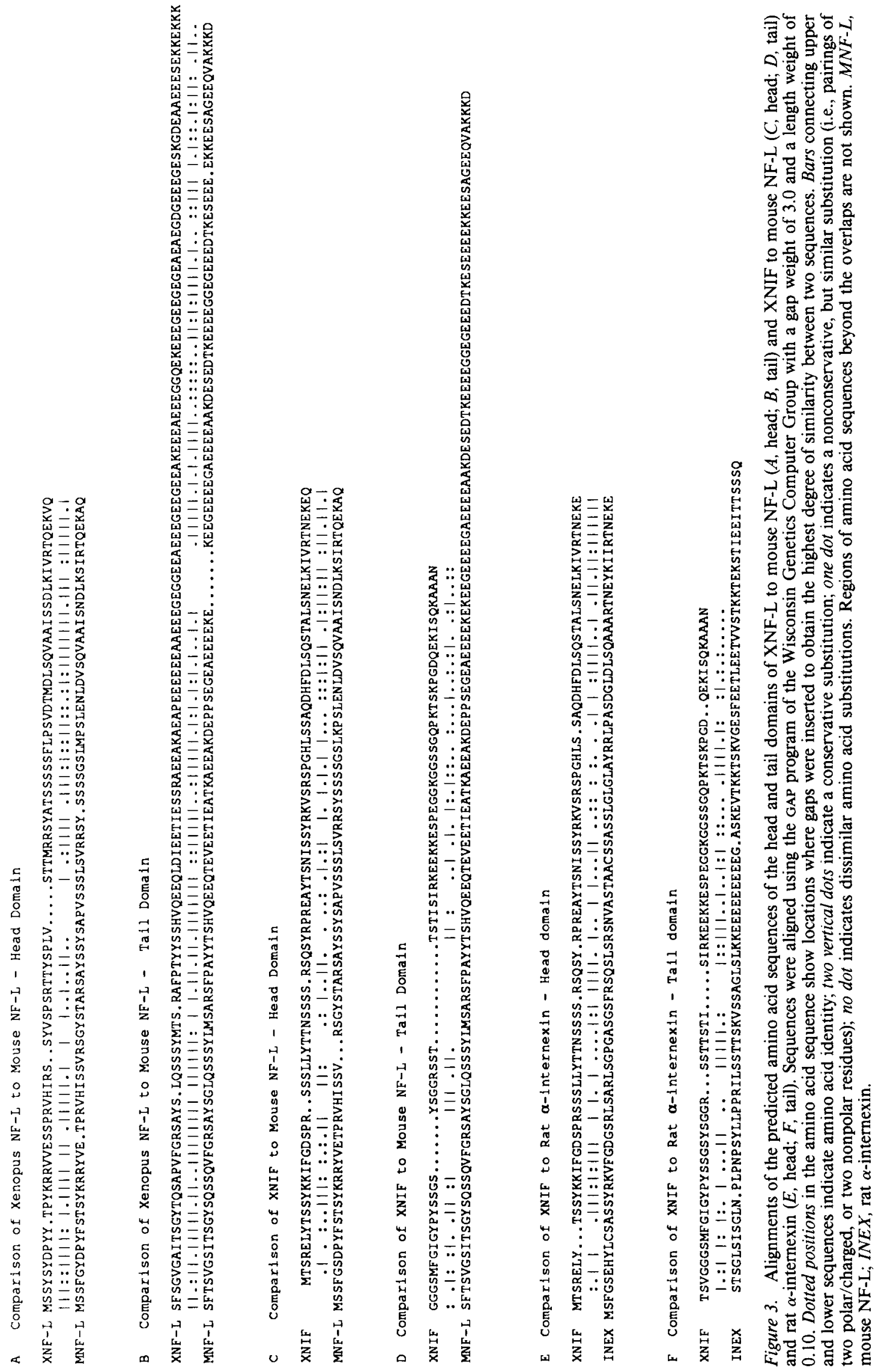


\section{XTC Brain Liver Muscle Skin Stage47 Ovary}

\section{S}

\section{$18 S$}

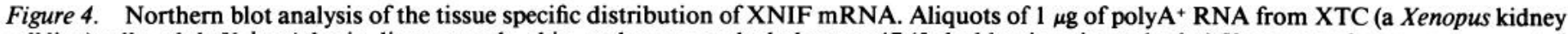
cell line) cells, adult $X$. laevis brain, liver, muscle, skin, and ovary, and whole stage 47 (5-d-old swimming tadpoles) Xenopus embryos were separated on $1.2 \%$ denaturing agarose gels, blotted to nylon membrane, and hybridized with a cDNA probe to XNIF (XNK3) as described in Materials and Methods. Positions of the $28 \mathrm{~S}$ and $18 \mathrm{~S}$ ribosomal RNAs are as indicated. A prominent $2.4 \mathrm{~kb}$ band was detected in adult brain and weakly in whole stage 47 embryos. The blot was exposed for $6 \mathrm{~d}$.

The possibility that XNIF represented the $X$. laevis homolog to NF-L was completely excluded after the remaining clones from the original screen were analyzed. The largest of these (XNF21) contained a partially completed open reading frame that was highly homologous to mouse NF-L and included the expected glutamic acid-rich region of the tail domain. Additional clones ( $\mathrm{H} 4$ and $\mathrm{H} 10)$ representing the mRNA encoded by XNF2 1 were obtained by screening a second $X$. laevis brain random hexamer primed cDNA library in $\lambda g t 10$. When assembled, the sequences of these clones predicted an intermediate filament protein (Fig. 2) with a predicted molecular weight of $61,825 \mathrm{Da}$, which we have termed XNF-L, that showed a high degree of identity with mouse NF-L. When the amino acid sequences of XNF-L and mouse NF-L were aligned (Table 1), the central rod domains of these proteins were $78 \%$ identical. This level of identity is comparable to that seen between rat peripherin and Xenopus peripherin (Sharpe et al., 1989). Similarly, the alignment of predicted amino acid sequences encoding the head and tail domains of XNF-L with mouse NF-L (Fig. 3) revealed numerous identical amino acids and conservative substitutions among nonidentical residues. In the head domain, regions of the alignment did contain some short stretches of amino acid insertions and deletions that reduced the absolute identity, but clearly the overall conservation of sequence appeared to be maintained. The degree of identity between the head domains of XNF-L and mouse NF-L (65\%) was comparable to that seen between other Xenopus and mammalian cognate intermediate filament proteins (e.g., 70\% for Xenopus and hamster desmin, $57 \%$ for Xenopus and hamster vimentin, and $49 \%$ for Xenopus and rat peripherin). In addition, the majority of the differences (11 of 19) between aligned, but nonconservatively substituted amino acids in the head domain were due to single base changes, which is expected for closely homologous proteins (Fitch and Margoliash, 1967). Between tail domains of XNF-L and mouse NF-L, the overall identity was $60 \%$, comparable to that seen between Xenopus and rat peripherin. By these criteria, XNF-L appears to represent the Xenopus equivalent of mammalian NF-L.

\section{Neural-specific expression of XNIF mRNA demonstrated by Northern blot}

Intermediate filament proteins generally show tissue-specific patterns of expression (reviewed in Steinert and Roop, 1988). Initially, Northern blots were used to examine the tissue-specific expression of XNIF mRNA in the adult. As shown in Figure 4, cDNA probes specific for XNIF hybridized with a prominent $2.4 \mathrm{~kb}$ band seen only in adult Xenopus brain, but not other non-neuronal adult tissues. Thus, XNIF expression appeared restricted to the nervous system. XNIF mRNA was also detectable in whole stage 47 (5-d-old) tadpoles, indicating that XNIF might be present within developing neurons.

\section{Adult neuronal expression of XNIF $m R N A$}

In order to determine which cells within the nervous system expressed the XNIF mRNA, in situ hybridization with cRNA probes specific for XNIF was performed on sections of brain and spinal cord (Fig. 5). XNIF mRNA was easily detectable in neurons, but appeared absent from areas rich in glial cell bodies. For example, in the medulla at the level of the obex (Fig. 5A,B), XNIF mRNA was most abundant in the neuron-rich gray matter, including cells that could be identified as large reticular neurons by their size and position. However, XNIF mRNA was not detected in blood vessels, ependymal cells (e), or the white matter (w), which are regions rich in glial cell bodies. In the spinal cord (Fig. $5 C-F$ ), XNIF mRNA was abundant in motor neurons of the ventral horn (vh), which could be unambiguously identified by virtue of their position within the ventral horn and by the large size of their cell bodies (30-50 $\mu \mathrm{m}$ in diameter). As in the medulla, the XNIF cRNA probe did not hybridize with cell bodies in those regions known to be rich in glial cell bodies, such as the central canal (c) and the white matter.

\section{Analysis of the XNIF protein by Western blotting}

To characterize further the XNIF protein, antisera was raised against a synthetic peptide (KTSKPGDQEKI) made according to the amino acid sequence predicted from the XNIF cDNA. 

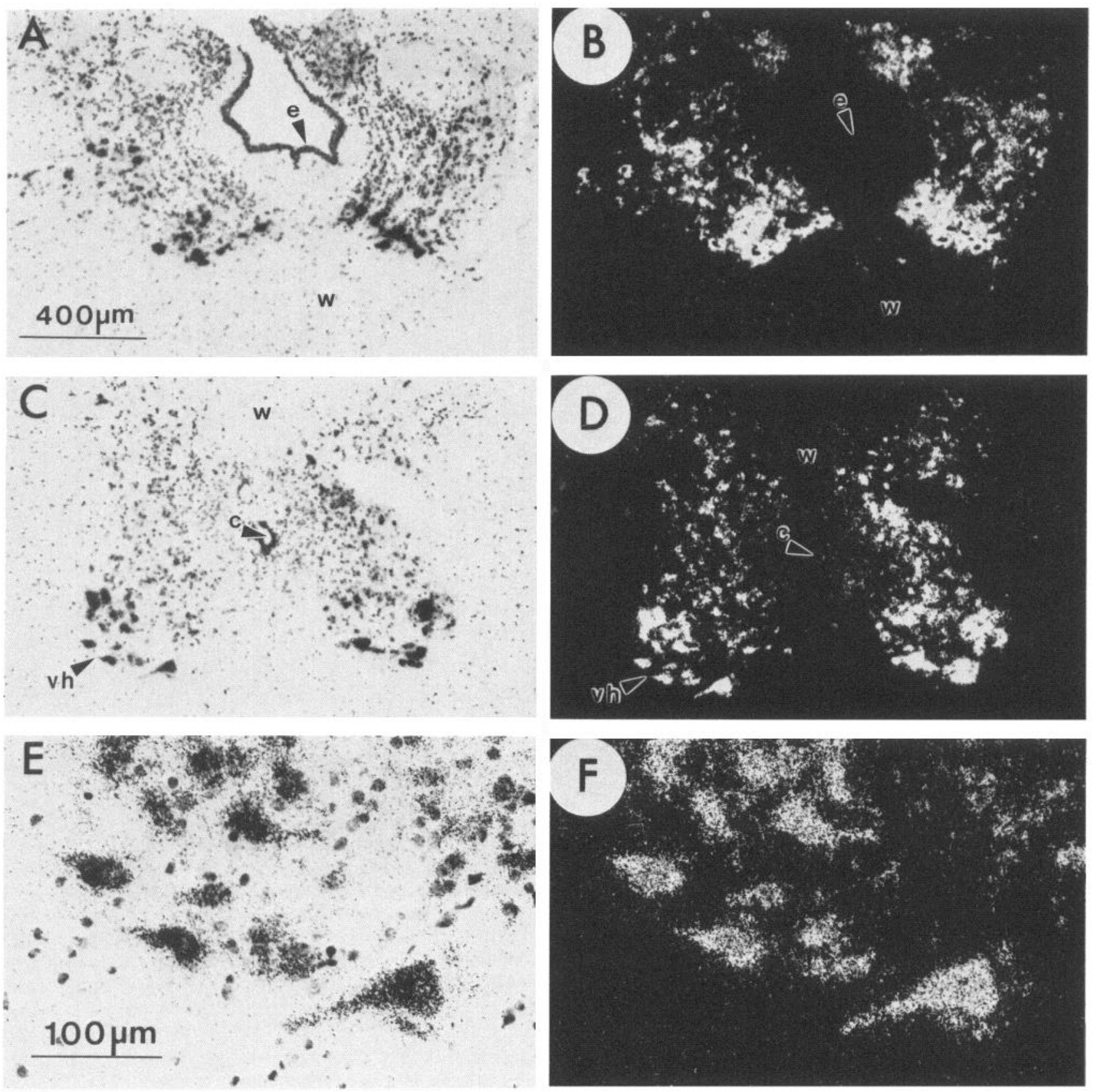

Figure 5. Distribution of XNIF mRNA in adult $X$. laevis nervous system as shown by in situ hybridization with cRNA probes: bright-field $(A$, $C, E)$ and corresponding dark-field $(B, D, F$, respectively) photomicrographs of transverse sections of medulla $(A, B)$, lumbar spinal cord $(C, D)$, and ventral horn $(E, F)$. The photomicrograph of the ventral horn $(E, F)$ is magnified from the region indicated by the arrowhead at $v h$ in $C$ and $D$. Cresyl violet-stained nuclei of unlabeled cells are seen in the bright-field photomicrographs. Abbreviations: $e$, ependymal cells; $c$, spinal cord central canal; $w$, white matter containing nuclei of glial cells. The $400 \mu \mathrm{m}$ scale bar is for $A-D$. The $100 \mu \mathrm{m}$ scale bar is for $E$ and $F$.

This sequence is found in the tail domain (doubly underlined in Fig. 1A), and was selected because monoclonal antibodies directed against epitopes in the tail domains of intermediate filament proteins tend to perform well in immunocytochemistry, and because this sequence showed no significant similarity with sequences in the GenBank (Los Alamos, NM) data base. On Western blots of spinal cord preparations enriched for intermediate filament proteins, the anti-XNIF antiserum (aXNIF, Fig. 6) reacted with a single band with an apparent molecular weight of $60 \mathrm{kDa}$. The identification of the XNIF protein as an intermediate filament protein was further confirmed because the anti-XNIF-immunoreactive protein co-ran with the lower of the two bands heavily stained by the aIFA antibody, which recognizes an epitope shared by nearly all intermediate filament proteins. Furthermore, antibodies directed against other known neurofilament proteins in $X$. laevis (aXNF-L, aXNF-M, aXNF-H) and an antibody directed against a Xenopus vimentinlike protein each stained bands distinct from that stained by the anti-XNIF antibody. Cytoskeletal preparations from sciatic nerve and brain gave similar results (data not shown). Thus, these data 
Figure 6. Western blots of preparations enriched for intermediate filament proteins from adult $X$. laevis spinal cord and separated by SDS-PAGE on $7.5 \%$ polyacrylamide gels. The numbered bars on the left indicate the positions and sizes (in kilodaltons) of proteins used as molecular weight standards. Arrowheads indicate the positions of immunostained bands representing XNIF $(a X N I F)$, Xenopus vimentin (aVIM), Xenopus NF-L $(a X N F-L)$, Xenopus NF-M $(a X N F-M)$, and Xenopus NF-H (aXNF-H). Abbreviations indicate the antibody used to stain each blot: $a I F A$, pan-specific antiintermediate filament protein antibody; $a X N I F$, anti-XNIF antibody; aVIM, anti-vimentin antibody; $a X N F-L$, anti-Xenopus NF-L antibody; $a X N F-M$, anti-Xenopus NF-M antibody; $a N F-L$, anti-Xenopus NF-H antibody. The $a X N F-L$ detects a doublet, both of which are thought to be XNF-L (Szaro and Gainer, 1988b). The antivimentin antibody used produced variable staining depending upon the cytoskeletal preparation. The band identified in this immunoblot migrated at a similar position, but stained less intensely, than in other work (Szaro and Gainer, 1988a).
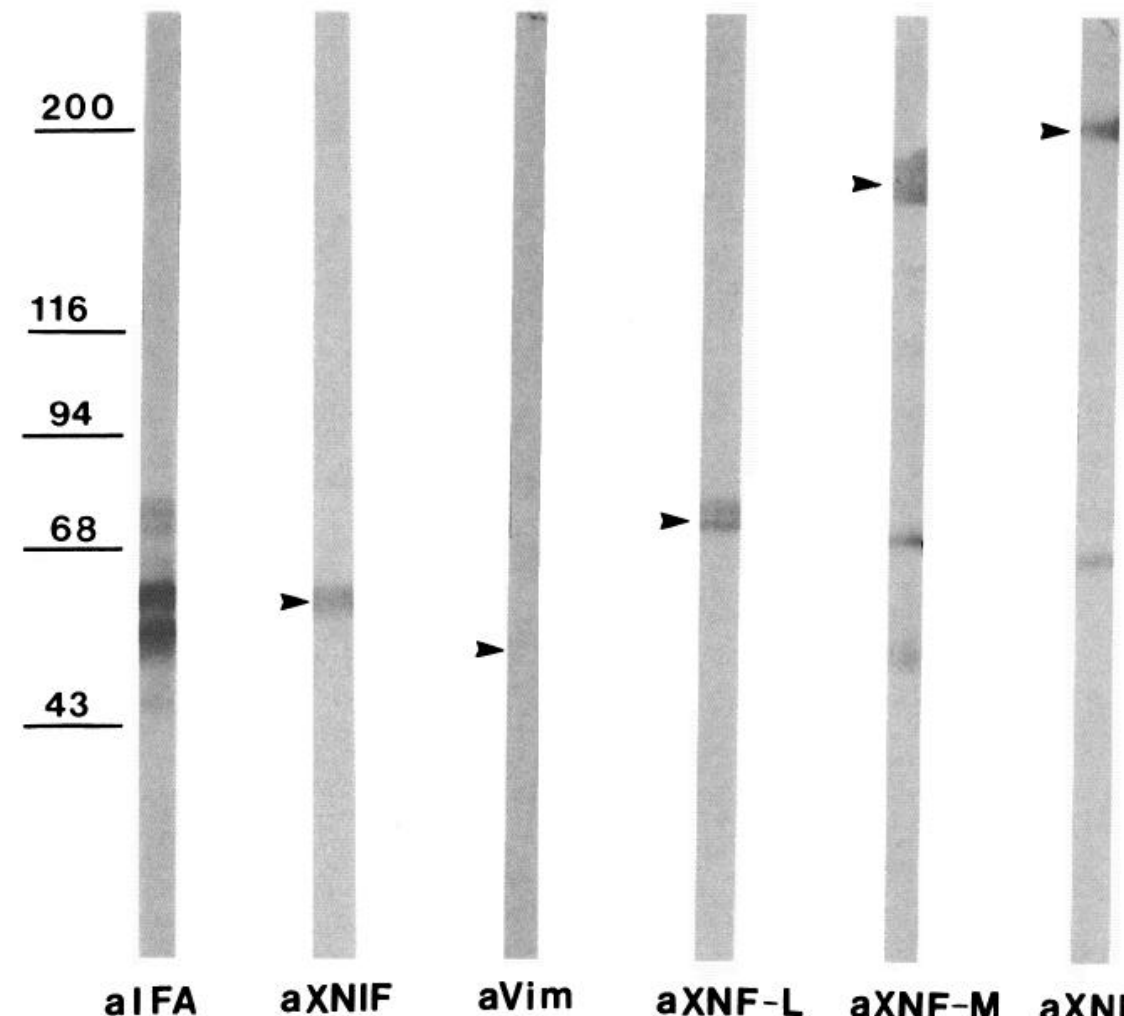

alFA
aXNF-L

aXNF-M confirmed both the existence of the XNIF protein, and its consideration as a unique, novel, neuronal intermediate filament protein.

\section{Immunocytochemistry with the anti-XNIF antibody in adult nervous system}

The anti-XNIF antibody was used in immunocytochemical assays to confirm the expression of the XNIF protein in neurons and to examine its distribution in axons and dendrites. For example, in sections of peripheral nerve (Fig. $7 A-C$ ), anti-XNIF immunoreactivity was clearly axonal (Fig. $7 B$ ). This axonally restricted pattern of staining was similar to that obtained with another antibody directed against a different neurofilament protein, Xenopus NF-M (Fig. 7A). In contrast, an antibody directed against human GFAP, which previously was shown to crossreact with intermediate filament proteins in subsets of Xenopus glial cells (Szaro and Gainer, 1988b), stained scattered extraaxonal processes (Fig. 7C) different from those stained by the anti$\mathrm{XNIF}$ and anti-XNF-M antibodies.

In addition, because several antibodies specific for neurons (e.g., anti-XNF-L, anti-XNF-M) were available, the issue of whether the XNIF protein was expressed in all neurons, or only a subset of them, could be addressed directly. For example, in sections of dorsal root ganglia, the anti-XNIF antibody (Fig. $7 E$ ) preferentially stained small neurons and thin processes in contrast to the relatively homogeneous staining of all perikarya and axons by the anti-XNF-M antibody (Fig. 7D). Moreover, whereas the anti-XNIF antibody preferentially stained small neurons, the anti-XNF-L antibody preferentially stained the larger perikarya and thicker processes of the dorsal root ganglia (Fig. $7 F$ ). Thus, these data confirm the identification of XNIF as a specifically neuronal protein and demonstrate its abundance in axons. They also further suggest that XNIF and XNF-L are preferentially expressed in different subsets of adult neurons.

\section{$X N I F$ expression in the developing Xenopus nervous system}

Previous studies of the expression of Xenopus NF-L, NF-M, and NF-H performed with monoclonal antibodies indicated that in Xenopus, NF-M is preferentially expressed earlier than the other two (Szaro and Gainer, 1988a,b; Szaro et al., 1989). In these studies, anti-XNF-M immunoreactivity was found in differentiating neurons by stage 24 ( $26 \mathrm{hr}$ old), whereas anti-XNF-L and -XNF-H immunoreactivities were detected only weakly in neurons at stage $35 / 36(50 \mathrm{hr}$ ). At stages $42-45$ (early swimming tadpoles), anti-NF-M immunoreactivity is also abundant whereas anti-XNF-L and XNF-H immunoreactivities remain relatively much weaker (Szaro and Gainer, 1988a; Szaro et al., 1989). Thus, it was of interest to examine whether XNIF protein was abundant at earlier stages, like XNF-M, or would be detectable only later, like XNF-L and XNF-H.

By Northern analysis of total RNA, XNIF mRNA was detectable by stage $24(26 \mathrm{hr})$ and increased monotonically throughout development (Fig. 8A). In comparison, except for a transient expression at stage 18 , XNF-L mRNA was not detectable until stage $35 / 36$ by this assay (Fig. $8 B$ ). At stages $35 /$ 36 and stage 42 , XNF-L mRNA still appeared relatively less abundant than XNIF mRNA. Of the stages examined, only after metamorphosis (2-3 months postmetamorphosis) were levels of XNIF and XNF-L mRNA comparable. Thus, these data were consistent with immunocytochemical data of the relative abundance and distribution of these proteins during development (see below for XNIF; for XNF-L, see Szaro and Gainer, 1988a; Szaro et al., 1989).

Immunocytochemical analysis of the distribution of the XNIF 

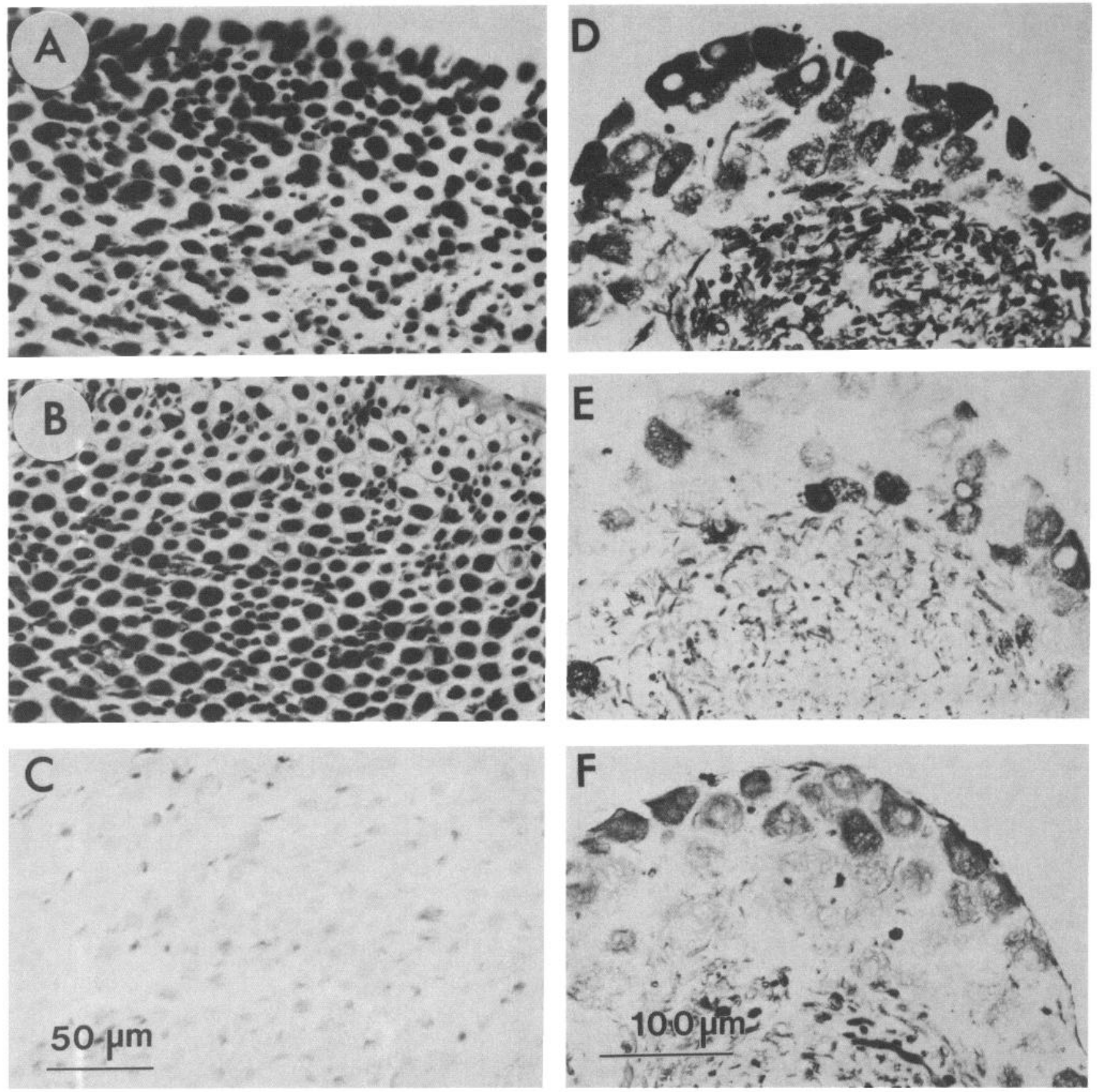

Figure 7. The distribution of selected intermediate filament protein immunoreactivities in the adult PNS. Transverse sections from sciatic nerve $(A-C)$ and dorsal root ganglion $(D-F)$ were stained by antibodies to XNF-M $(A, D)$, XNIF $(B, E)$, GFAP $(C)$, and XNF-L $(F)$. Anti-XNIF immunoreactivity in the sciatic nerve $(B)$ was clearly axonal as seen by comparing $B$ to sections stained by anti-XNF-M $(A)$ and anti-GFAP $(C)$ antibodies. In the dorsal root ganglion, anti-XNIF immunoreactivity $(E)$ was preferentially found in smaller perikarya and finer processes, as compared to anti-NF-L immunoreactivity $(F)$ found in larger perikarya and thicker processes, and anti-XNF-M immunoreactivity $(D)$, which was homogeneously distributed. The scale for $A-C$ is shown in $C$, and for $D-F$ in $F$.

protein in developing Xenopus confirmed its abundance in differentiating neurons, and revealed a pattern of expression that closely resembled (although was not identical to) the distribution of XNF-M seen previously (Szaro et al., 1989). Like XNF-M immunoreactivity, XNIF immunoreactivity was detectable in differentiating neurons by stage 24 , but unlike XNF-M, XNIF immunoreactivity was abundant in the cement gland as well (not shown, but see Fig. 9, stage 35/36). By stage 35/36 (50 hr; Fig. 9), anti-XNIF immunoreactivity was widely distributed in neurons throughout the developing nervous system. Within the stage $35 / 36$ nervous system, anti-XNIF immunoreactivity (Fig. 9) was seen in the same structures reported to contain XNF-M immunoreactivity (Szaro et al., 1989), including the cranial nerves, optic axons, ventral longitudinal tracts within the CNS, reticular neurons, primary motoneurons and their axons, and dorsal Rohon-Beard cells. In contrast, XNF-L immunoreactivity at this stage is only weakly detectable in some spinal cord neurons, and not at all in reticular neurons or the optic nerve (Szaro and Gainer, 1988a; Szaro et al., 1989).

At later stages [e.g., stage 41 (Figs. 10A,B;11A), stage 45 (Figs. 

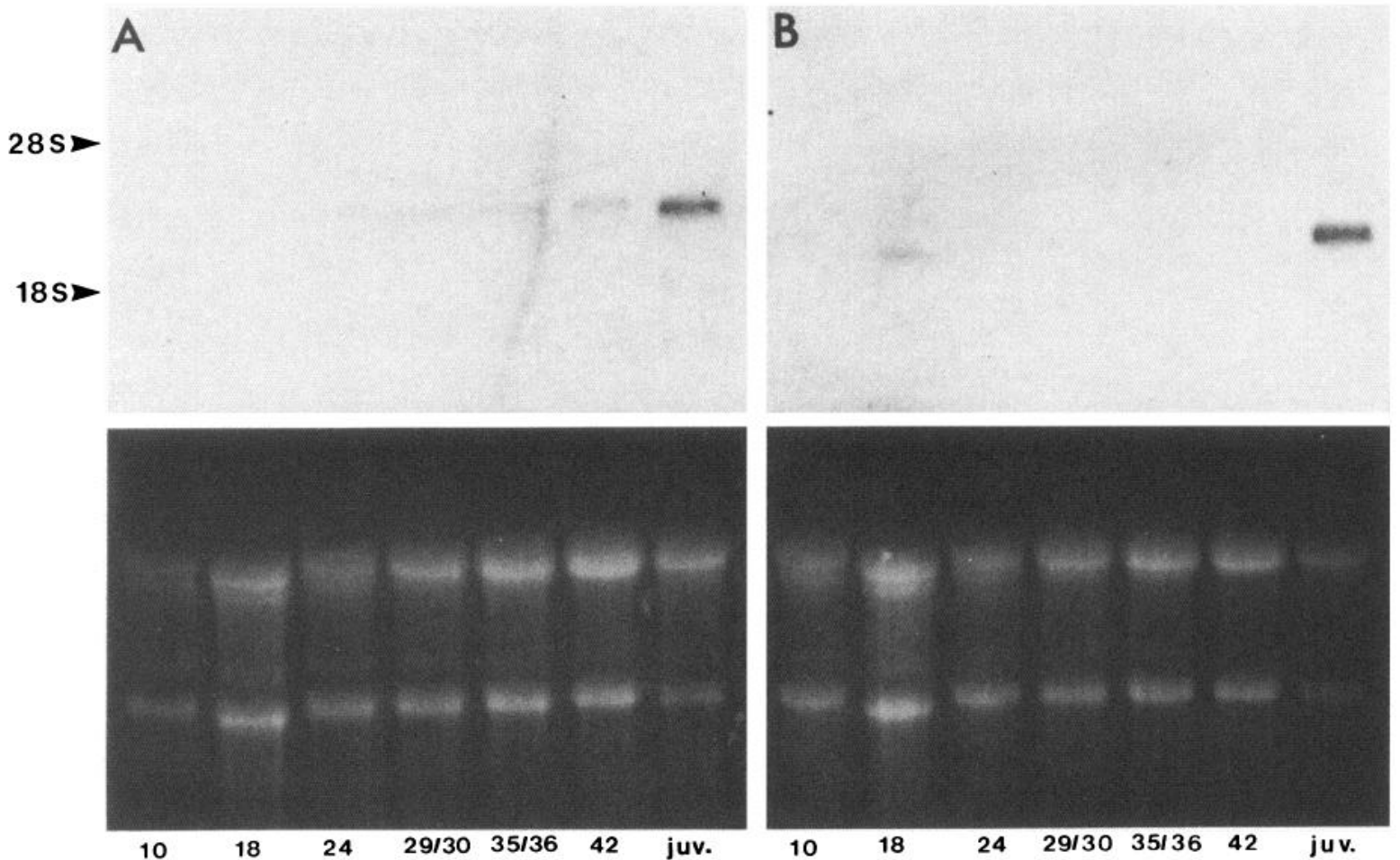

Figure 8. Northern blot analysis of XNIF $(A)$ and XNF-L $(B)$ mRNA expression during development. Identical aliquots of $10 \mu \mathrm{g}$ of total RNA from indicated stages or juvenile brain were separated and transferred to nitrocellulose as described. Blots were then hybridized with identical amounts $\left(20 \mathrm{ml}\right.$ at $\left.5 \times 10^{5} \mathrm{cpm} / \mathrm{ml}\right)$ of labeled cDNA probes for XNIF and XNF-L, washed, and exposed to x-ray film over the same time period (7 d). The lower panel shows the ethidium bromide-stained agarose gels prior to transfer. XNIF mRNA was first detectable at stage 24 , whereas XNF-L mRNA was detected transiently at stage 18 , and then not again until stage $35 / 36$. RNA in the stage 18 lanes migrated slightly faster than the others.

$10 C, D ; 11 B, C)]$ when anti-XNF-L immunoreactivity is still relatively weak (Szaro and Gainer, 1988a; Szaro et al., 1989), antiXNIF immunoreactivity was abundant within neurons and axons. Neuronal structures stained by the anti-XNIF antibody included cranial nerves (Fig. $10 A, B$ ), longitudinal tracts of the CNS (Fig. 10A-D), and axons of Mauthner's neurons (Fig. 10B). In addition, by stage 45 when the retina has differentiated, antiXNIF immunoreactivity was seen in the retinal ganglion cell layer, and the inner and outer nuclear layers (Fig. 11B,C). At these stages, anti-XNF-M immunoreactivity is similarly distributed, except that in the retina it is restricted to retinal ganglion cells (Szaro et al., 1989). Thus, within the early developing nervous system, XNIF is an important marker for differentiated neurons and their axons and, as in the adult, exhibits a different pattern of expression than that reported for the other Xenopus neurofilament proteins.

\section{Discussion}

In this article, we report a novel neuronal intermediate filament protein in $X$. laevis, XNIF, and describe its distribution in the developing and adult nervous system. During development, the XNIF protein was abundant within axons and perikarya of the earliest neurons to differentiate. XNIF mRNA and protein expression persisted in a subset of neurons into adulthood.

\section{$X N I F$ as a novel neurofilament protein}

The classic neurofilament proteins, comprising low (NF-L), middle (NF-M), and high (NF-H) molecular weight forms (Hoff- man and Lasek, 1975), have been identified among representatives of all vertebrate groups (Phillips et al., 1983), including $X$. laevis (Szaro and Gainer, 1988a). Neurofilament proteins were first classified collectively as type IV intermediate filament proteins (Steinert and Parry, 1985), and another type IV neurofilament protein, $\alpha$-internexin, has recently been described in mammals (Chiu et al., 1989; Fliegner et al., 1990; Kaplan et al., 1990).

Other neuron-specific intermediate filament proteins that cannot be classified as type IV intermediate filament proteins have also been identified. Mammalian peripherin, found preferentially in small neurons of the PNS, is more closely related to the type III intermediate filament proteins such as desmin, vimentin, and GFAP as opposed to the type IV neurofilament proteins (Aletta et al., 1988; Parysek et al., 1988; Thompson and Ziff, 1989). A peripherin-like protein has also been described in $X$. laevis, where it is present during early developmental stages primarily in the anterior nervous system (Sharpe et al., 1989). In the invertebrates, the low molecular weight neurofilament proteins of the squid differ from all vertebrate cytoplasmic intermediate filament proteins, including the neurofilament proteins. Although still classifiable as intermediate filament proteins, squid neurofilament proteins have a rod domain that bears closer structural resemblance to the nuclear intermediate filament lamins (Szaro et al., 1989). Both lamins (McKeon et al., 1986) and squid neurofilament proteins (Szaro et al., 1991) have a rod domain that contains six additional heptads than the vertebrate cytoplasmic intermediate filament proteins in general. 
The classification of XNIF as a neuronal intermediate filament protein was based upon the presence of a typical rod domain sequence, the enrichment of anti-XNIF immunoreactivity in cytoskeletal preparations, the expression of its mRNA in neurons, and the presence of the XNIF protein in axons. The lack of sufficient homology with any previously characterized intermediate filament protein, either neuronal or non-neuronal, led to the consideration of XNIF as a novel neurofilament protein. The XNF-L sequence reported here also supports the consideration of XNIF as a new neurofilament protein. The overall identity between Xenopus NF-L and mouse NF-L sequences in each domain was less than that seen between hamster and Xenopus desmin and vimentin, but similar to that seen between the peripherins (Table 1), and consistent with observed cross-reactivities between anti-Xenopus- and anti-mammalian-NF-L antibodies (Szaro and Gainer, 1988a). Some of the largest differences between Xenopus and mouse NF-L occurred in the polyglutamic acid region. Such variability has not been described among mammalian NF-Ls, but is a feature of both NF-M and NF-H sequences (see Lees et al., 1988, for discussion).

The placement of XNIF among the classes of the intermediate filament protein family is still uncertain. Direct sequence comparisons between XNIF and known type III intermediate filament proteins such as desmin, vimentin, and peripherin exhibited relatively low percentages of identity compared to those typically seen among the type III proteins themselves (Table 1). In addition, certain amino acid sequences typical of type III intermediate filament proteins were lacking. These included the sequence IKTIETRDGEVV, which is conserved in the tail domains of type III intermediate filament proteins, including Xenopus peripherin (Sharpe et al., 1989). The highest percentage identities with XNIF were seen among the type IV neurofilament proteins (e.g., see comparisons with $\alpha$-internexin and mouse NF-L in Table 1). In addition, the tail domain of XNIF contains the sequence KEEKKE, also seen in human NF-M. Moreover, the degree of identity within the rod domain between XNIF and these other neurofilament proteins (e.g., $62 \%$ for rat $\alpha$-internexin, $60 \%$ for mouse NF-L) was greater than that seen between mouse NF-L and rat NF-M (54\%) and comparable to that seen between two type III intermediate filament proteins, mouse GFAP, and human vimentin (64\%).

These comparisons suggest that XNIF may belong to the type IV neurofilament family. A further parallel can be drawn between $\alpha$-internexin and XNIF due to their similar appearance early in embryogenesis prior to NF-L expression (and see below). It is tempting to consider XNIF to be the Xenopus equivalent of $\alpha$-internexin. We have used sequence comparison, the most conservative measure, as the sole determinant of equivalence of these proteins. When tail domain sequences were considered, XNIF lacked such features as the glutamic acid-rich region typically seen in the type IV neurofilaments and had no significant homology in other regions of the tail domain (Fig. 3 ). There is slightly greater homology in the head domains of XNIF and $\alpha$-internexin (Fig. 3). Most of this is in the $\mathrm{H}_{1}$ domain, a very highly conserved class-specific sequence (Steinert and Parry, 1985). This is consistent with XNIF being a type IV intermediate filament protein but does not aid in determining whether these two proteins are equivalent. In addition, no immunoreactivity was detected in rat CNS by aXNIF antiserum (L. Charnas, unpublished observations).

Additional work to clarify the relationship of XNIF to $\alpha$-internexin and other type IV intermediate filament proteins is
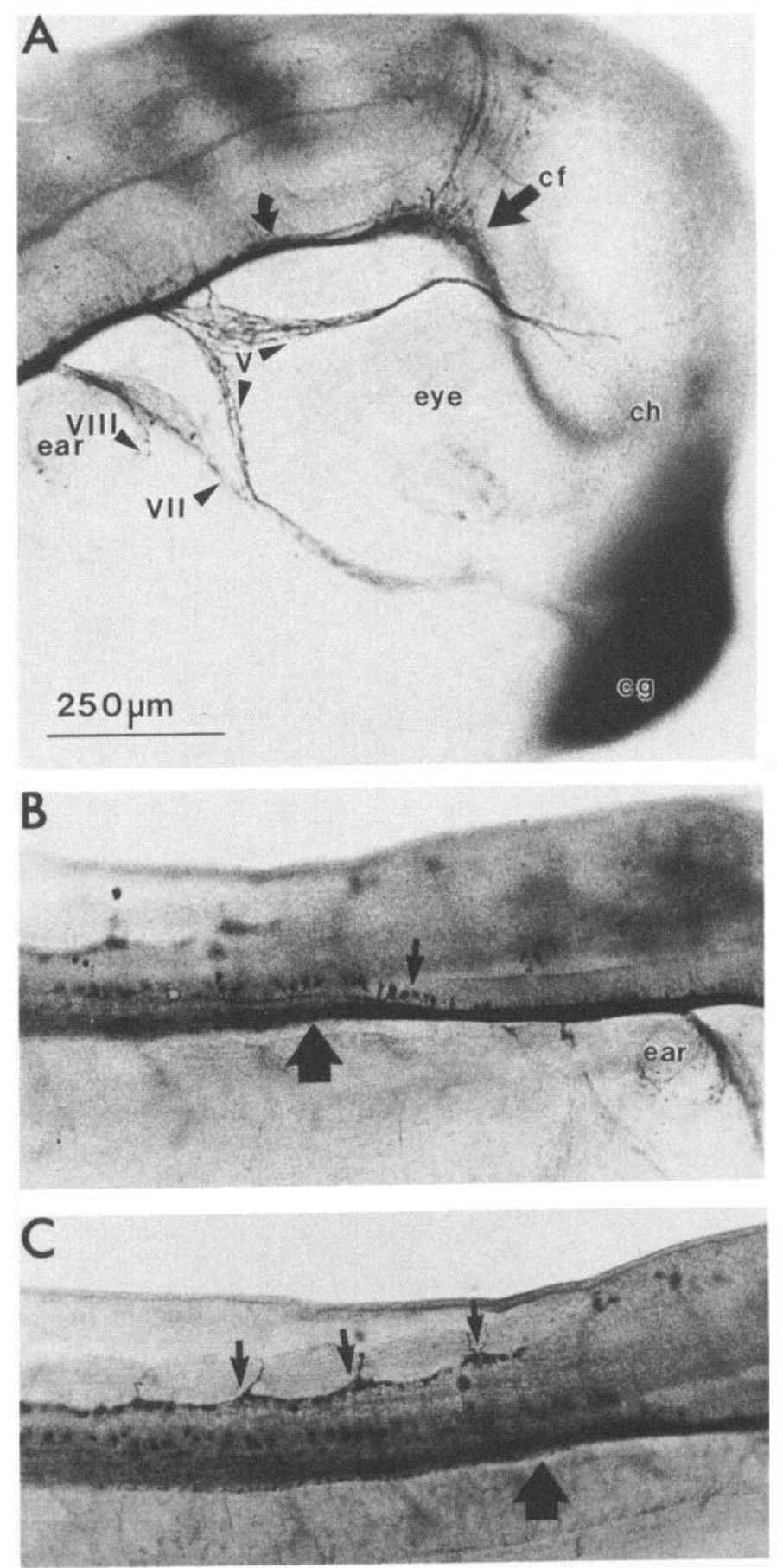

Figure 9. Distribution of anti-XNIF antibody immunoreactivity in a stage $35 / 36$ embryo. $A$, Whole-mounted embryo showing the head stained by the anti-XNIF antibody. Arrowheads at $V, V I I$, and $V I I I$ indicate positions of these respective cranial nerves. The curved arrow points to ventral longitudinal tracts in the brain. The arrow at $c f$ points to the cephalic flexure; $c h$ and $c g$ indicate the optic chiasm and cement glands, respectively. $B$. View from the same embryo shown in $A$, at the site of the future cervicomedullary junction. The large arrow points to ventral longitudinal tracts of axons; the small arrow shows ventral neuronal perikarya. $C$, Same as in $B$, but with a different plane of focus. The large arrow points to the same position as the large arrow in $B$. The smaller arrows point to perikarya and processes of dorsal Rohon-Beard neurons. 

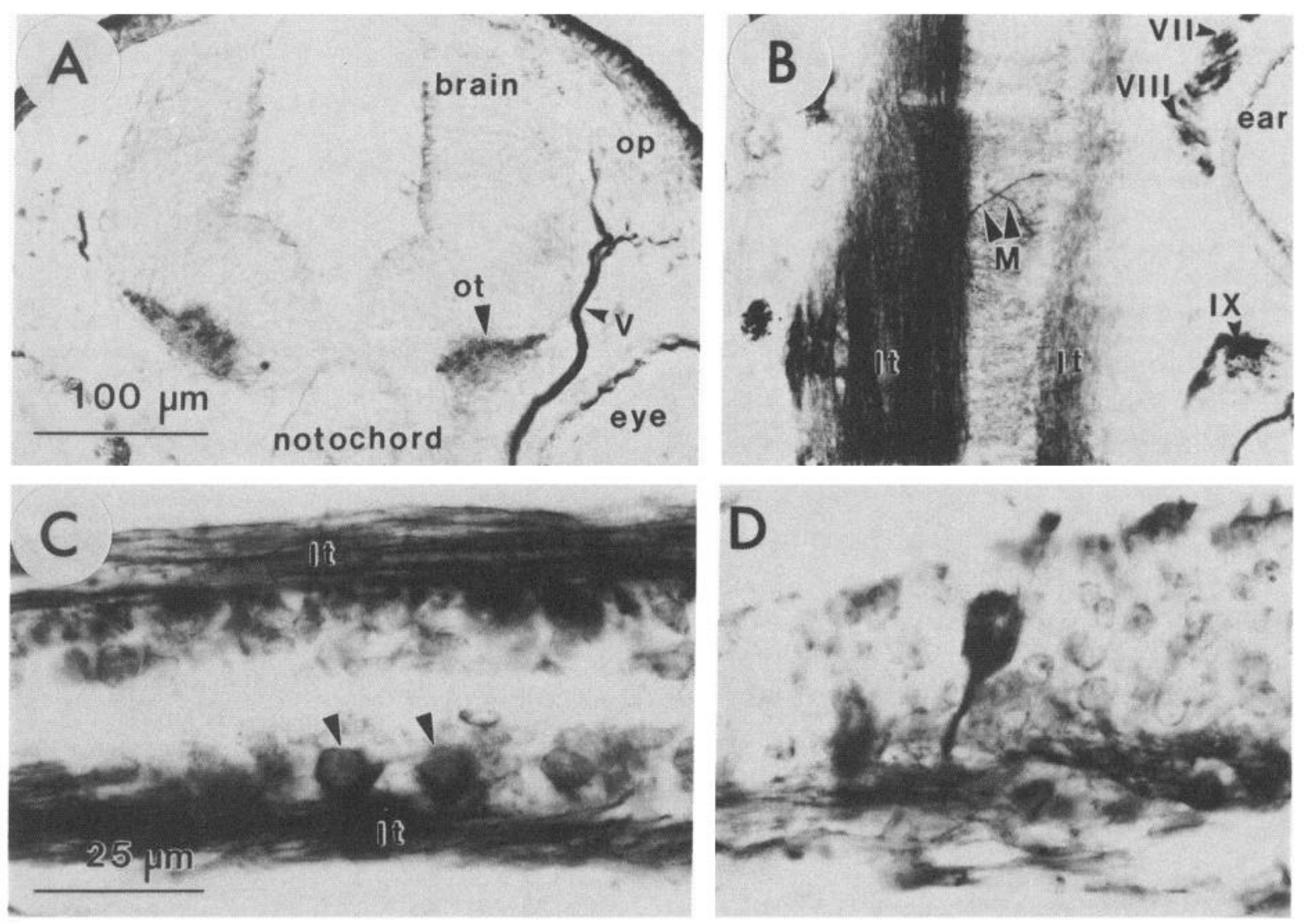

Figure 10. Anti-XNIF antibody immunoreactivity in the developing CNS and PNS. A, Horizontal section through the head of a stage 41 (3-dold) swimming tadpole; anterior is up. Anti-XNIF antibody immunoreactivity is seen in the optic tract (ot), and Vth cranial nerve ( $V$ ). op, olfactory placode. B, Horizontal section through the rhombencephalon of the embryo in $A$; anterior is up. Arrowheads at $V I I, V I I I$, and $I X$ point to antiXNIF immunoreactivity in respective cranial nerves. XNIF immunoreactivity is also seen in longitudinal tracts of axons $(l t)$ and in the axons of the Mauthner neurons at the point of decussation (arrowheads at $M$ ). $C$, Horizontal section (anterior is to the right) showing anti-XNIF-immunoreactive neuronal cell bodies (arrowheads) and axons ( $l t$, longitudinal tracts) of the tail spinal cord of a stage 45 (5-d-old) swimming tadpole. $D$, An anti-XNIF antibody-immunoreactive, rhombencephalic neuronal perikarya from the tadpole shown in $C$. The $100 \mu \mathrm{m}$ scale bar is for $A$ and $B$; the $25 \mu \mathrm{m}$ scale bar is for $C$ and $D$.

needed. Since type IV intermediate filament protein genes have unique intron positions, a more definitive classification of XNIF will require analysis of genomic clones to determine the distribution of introns and exons (see Lewis and Cowan, 1986; Ching and Liem, 1991), and demonstration that XNIF forms copolymers with other intermediate filament proteins.

\section{The developmental expression of XNIF}

The Northern blots and the immunocytochemical data indicated that XNIF is one of the earliest neurofilament proteins expressed, coincidental with axonal outgrowth. The temporal expression of XNIF parallels that previously reported for XNF-M (Szaro and Gainer, 1988a,b; Szaro et al., 1989). The coincidental expression of XNIF and XNF-M may solve a paradox raised in previous studies of neurofilament expression in Xenopus embryos (Szaro and Gainer, 1988a,b; Szaro et al., 1989). In these immunocytochemical studies, NF-M was detectable with monoclonal antibodies before NF-L. In other organisms with more than one size class of neurofilament proteins, NF-M usually requires the additional presence of a lower molecular neurofilament protein in order to form filaments (Gardner et al., 1984). Due to the vagaries of immunocytochemistry, the possibility existed that NF-L was present together with NF-M but in a form undetectable by the antibodies used. However, the consistencies between these earlier immunocytochemical studies and the Northern blots (Fig. 8), together with the presence of anti-XNIF immunoreactivity in these earliest neurons, suggest that the XNIF protein fulfills the role of the low molecular weight neurofilament protein in these cells. The observation that XNIF protein appears to precede NF-L protein expression in Xenopus has a similar parallel in the rat, in which $\alpha$-internexin expression prefaces that of the NF-L protein (Kaplan et al., 1990). Whether the successive expressions of XNIF and XNF-L proteins represent the differentiation of separate populations of neurons, or a developmental sequence within the same neurons, remains to be determined.

XNIF immunoreactivity was seen in all the retinal layers after stage 42 , and in the cement gland. The expression of XNIF in the embryonal cement gland does not conflict with the view that XNIF is a neuronal intermediate filament protein. The cement gland is a transitory structure in Xenopus and derives from the anterior sense plate, a structure that also gives rise to placodal neurons (Jamrich and Sato, 1989). Furthermore, seemingly inappropriate transitory expression of adult intermediate filament proteins in embryonal structures has been reported before (Kemler et al., 1981; LaFlamme et al., 1988). This may reflect either an efficient use of a limited number of structural genes during development or underlying complex relationships 

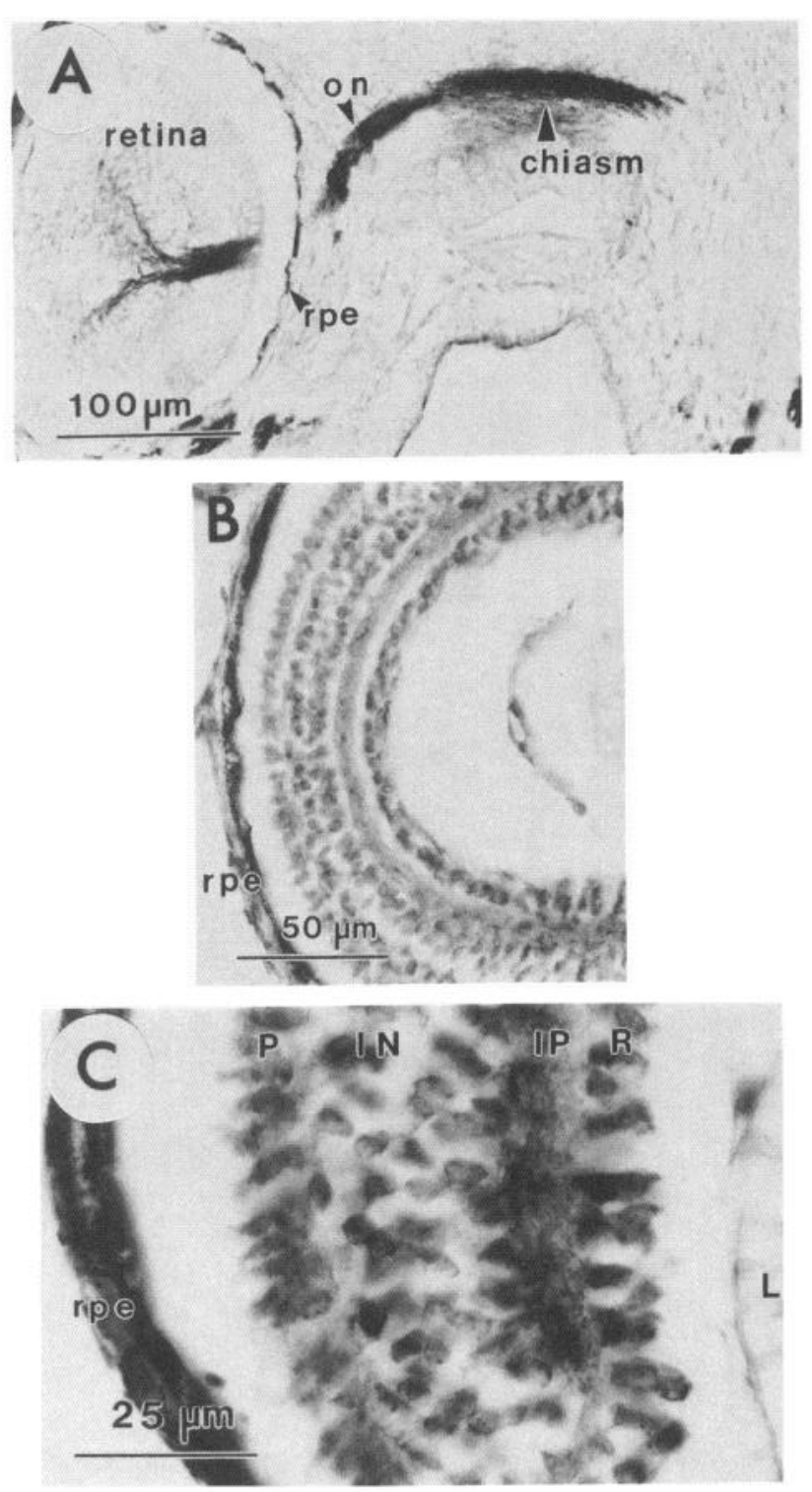

Figure 11. Anti-XNIF antibody immunostaining in the developing eye. $A$, Anti-XNIF-immunoreactive retinal ganglion cell fibers projecting from the retina, through the optic nerve (on) and optic chiasm of a stage 41 tadpole. This stage is just prior to the differentiation of the other cell layers of the retina. $B$, Anti-XNIF immunoreactivity is present in all retinal cell layers of a stage 45 (5-d-old) tadpole eye. The retinal pigment $(r p e)$ is naturally pigmented at this stage and is not immunostained. $C$, The retina shown in $B$ at higher magnification. $P$, Photoreceptor cell layer; $I N$, interneuron cell layer; $I P$, inner plexiform layer; $R$, retinal ganglion. The retinal pigmented epithelium (rpe) is naturally pigmented at this stage. The apparent staining of the outer layer $(L)$ is a nonspecific staining artifact. In all sections, anterior is up.

among factors responsible for gene regulation during differentiation. In this regard, the apparent transient expression of XNF-L mRNA at stage 18 is also interesting. The location of this expression within the embryo and the reasons for its apparent early developmental burst are at present unknown. It may be a manifestation of early cell phenotypic determination prior to morphologic signs of neuronal differentiation. Thus, this expression may serve as a useful developmental marker for neuronal commitment and warrants further investigation.

The significance of the expression of multiple forms of neu- rofilament proteins in the nervous system remains unclear. However, the utility of the frog $X$. laevis as a model system for early stages of vertebrate neuronal development offers experimental prospects for examining some of the possibilities. Intermediate filament proteins have already been used as markers for the differentiation of cellular phenotypes to study intercellular inductive interactions in epithelial and neural differentiation (Sargent et al., 1986; Sharpe et al., 1989). Injecting genetic constructs of cytokeratin genes (type I and II intermediate filament proteins) with altered putative control domains into Xenopus embryos has offered further prospects of directly studying the genetic mechanisms that control intermediate filament gene expression in development (Dawid and Sargent, 1988). Results obtained from the injection of antibodies to XNF-M into embryonic blastomeres (Szaro et al., 1991a) have suggested that neurofilament proteins may be important structurally for axon development. Since the XNIF protein is itself expressed in these early developing neurons and their axons, it provides both an additional important marker for neuronal differentiation and another target for perturbation studies of neurofilaments.

\section{References}

Aletta JM, Angeletti R, Liem R, Purcell C, Shelanski ML, Greene LA (1988) Relationship between the nerve growth factor-regulated clone 73 gene product and the 58 -kilodalton neuronal intermediate filament protein (peripherin). J Neurochem 51:1317-1320.

Altstein M, Whitnall MH, House S, Key S, Gainer H (1988) An immunocytochemical analysis of oxytocin and vasopressin prohormone porcessing in vivo. Peptides 9:87-105.

Bailey JM, Davidson N (1976) Methylmercury as a reversible denaturing agent for agarose gel electrophoresis. Anal Biochem 70:75-85.

Ching G, Liem R (1991) Structure of the gene for the neuronal intermediate filament protein alpha-internexin and functional analysis of its promoter. J Biol Chem 266:19459-19468.

Chiu FC, Barnes EA, Das K, Haley J, Socolow P, Macaluso FP, Fant J (1989) Characterization of a novel $66 \mathrm{kd}$ subunit of mammalian neurofilaments. Neuron 2:1435-1445.

Davis LG, Dibner MD, Battey JF (1986) Basic methods in molecular biology. New York: Elsevier.

Dawid IB, Sargent TD (1988) Xenopus laevis in developmental and molecular biology. Science 240:1443-1448.

Dent JA, Polson AG, Klymkowsky MW (1989) A whole mount immunocytochemical analysis of the expression of the intermediate filament protein vimentin in Xenopus. Development 105:61-74.

Devereaux J, Haeberli P, Smithies O (1985) A comprehensive set of sequence analysis programs for the VAX. Nucleic Acids Res 12:387395.

Fitch W, Margoliash E (1967) Construction of phylogenetic trees. Science 155:279-284.

Fliegner KH, Ching GY, Liem RK (1990) The predicted amino acid sequence of alpha-internexin is that of a novel neuronal intermediate filament protein. EMBO J 9:749-755.

Gardner EE, Dahl D, Bignami A (1984) Formation of 10-nanometer filaments from the $150 \mathrm{k}$-dalton neurofilament protein in vitro. J Neurosci Res 11:145-155.

Godsave SF, Anderton BH, Wylie CC (1986) The appearance and distribution of intermediate filament proteins during differentiation of the central nervous system, skin and notochord of Xenopus laevis. J Embryol Exp Morphol 97:201-223.

Gurdon JB (1967) African clawed frogs. In: Methods in developmental biology (Wilt FH, Wessells NK, eds), pp 75-84. New York: Crowell.

HenikoffS (1984) Unidirectional digestion with exonuclease III creates targeted breakpoints for DNA sequencing. Gene 28:351-359.

Hermann H, Fouquet B, Franke WW (1989a) Expression of intermediate filament proteins during development of Xenopus laevis. I. cDNA clones encoding different forms of vimentin. Development 105:279-298.

Hermann H, Fouquet B, Franke WW (1989b) Expression of intermediate filament proteins during development of Xenopus laevis. II. 
Identification and molecular characterization of desmin. Development 105:299-307.

Hoffman PN, Lasek RJ (1975) The slow component of axonal transport: identification of major structural polypeptides of the axon and their generality among mammalian neurons. J Cell Biol 66:351-366.

Hoperskaya OA (1975) The development of animals homozygous for a mutation causing periodic albinism in Xenopus laevis. J Embryol Exp Morphol 34:253-264.

Jamrich M, Sato S (1989) Differential genc expression in the anterior neural plate during gastrulation of Xenopus laevis. Development 105: 779-786.

Julien JP, Meyer D, Flavell D, Jurst J, Grosveld F (1986) Cloning and developmental expression of the murine neurofilament gene family. Mol Brain Res 1:243-250.

Kaplan MP, Chin SS, Fliegner KH, Liem RK (1990) Alpha-internexin, a novel neuronal intermediate filament protein, precedes the low molecular weight neurofilament protein (NF-L) in the developing rat brain. J Neurosci 10:2735-2748.

Kemler R, Brulet P, Schnebelen MT, Gaillard J, Jacob F (1981) Reactivity of monoclonal antibodies against intermediate filament proteins during embryonic development. J Embryol Exp Morphol 64:45-60.

LaFlamme SE, Jamrich M, Richter K, Sargent TD, Dawid I (1988) Xenopus endo $\mathrm{B}$ is a keratin preferentially expressed in the embryonic notochord. Genes Dev 2:853-862.

Lees JF, Shneidman PS, Skuntz SF, Carden MJ, Lazzarini RA (1988) The structure and organization of the human heavy neurofilament subunit (NF-H) and the gene encoding it. EMBO J 7:1947-1955.

Leonard D, Gorham JD, Cole P, Greene LA, Ziff EB (1988) A nerve growth factor-regulated messenger RNA encodes a new intermediate filament protein. J Cell Biol 106:181-193.

Lewis SA, Cowan NJ (1985) Genetics, evolution, and expression of the 68,000 -mol-wt neurofilament protein: isolation of a cloned cDNA probe. J Cell Biol 100:843-850.

Lewis SA, Cowan NJ (1986) Anomalous placement of introns in a member of the intermediate filament multigene family: an evolutionary conundrum. Mol Cell Biol 6:1529-1534.

McKeon FD, Kirshner MW, Caput D (1986) Homologies in both primary and secondary structure between nuclear envelope and intermediate filament proteins. Nature 310:463-468.

Nieuwkoop PD, Faber J (1967) A normal table of Xenopus laevis (Daudin). Amsterdam: North Holland.

Parysek LM, Goldman RD (1988) Distribution of a novel $57 \mathrm{kDa}$ intermediate filament (IF) protein in the nervous system. J Neurosci 8:555-563.

Parysek LM, Chishom RL, Ley CA, Goldman RD (1988) A type III intermediate filament gene is expressed in mature neurons. Neuron $1: 395-401$.

Phillips LL, Autilio-Gambetti L, Lasek RJ (1983) Bodian's silver method reveals molecular variation in the evolution of neurofilament proteins. Brain Res 278:219-223.

Pruss RM, Mirsky R, Raff MC, Thorpe R, Dowding AJ, Anderton BH (1981) All classes of intermediate filaments share a common antigenic determinant defined by a monoclonal antibody. Cell 27:419428.

Pudney M, Varma M, Leake CJ (1973) Establishment of a cell line (XTC2) from the South African clawed toad Xenopus laevis. Experientia 29:466-467.

Quax W, Egberts WV, Hendricks W, Quax JY, Bloemendal H (1983) The structure of the vimentin gene. Cell 35:215-223.
Quax W, van der Heuvel R, Egberts WV, Quax JY, Bloemendal H (1984) Intermediate filaments from BHK-2l cells; demonstration of distinct genes for desmin and vimentin in all vertebrate classes. Proc Natl Acad Sci USA 81:5970-5974.

Quitschke W, Schechter N (1984) 58,000 Dalton intermediate filament proteins of neuronal and nonneuronal origin in the goldfish visual pathway. J Neurochem 42:569-576.

Quitschke W, Jones PS, Schechter N (1985) Survey of intermediate filament proteins in optic nerve and spinal cord: evidence for differential expression. J Neurochem 44:1465-1476.

Raff M, Fields K, Hakomori S, Mirsky R, Pruss R, Winter J (1979) Cell-type-specific markers for distinguishing and studying neurons and the major classes of glial cells in culture. Brain Res 174:283-308.

Richter K, Grunz H, Dawid IB (1988) Gene expression in the embryonic nervous system of Xenopus laevis. Proc Natl Acad Sci USA 85:8086-8090.

Sanger F, Nicklen S, Coulson A (1977) DNA sequencing with chainterminating inhibitors. Proc Natl Acad Sci USA 74:5463-5467.

Sargent TD, Jamrich M, Dawid IB (1986) Cell interaction and control of gene activity during early development of Xenopus laevis. Dev Biol 114:238-246.

Sharpe CR (1988) Developmental expression of a neurofilament-M and two vimentin-like genes in Xenopus laevis. Development 103: 269-277.

Sharpe CR, Pluck A, Gurdon JB (1989) XIF3, a Xenopus peripherin gene, requires an inductive signal for enhanced expression in anterior neural tissue. Development 107:701-714.

Steinert PM, Parry D (1985) Intermediate filaments: conformity and diversity of expression and structure. Annu Rev Cell Biol 1:41-64.

Steinert PM, Roop DR (1988) Molecular and cellular biology of intermediate filaments. Annu Rev Biochem 57:593-625.

Szaro BG, Gainer H (1988a) Identities, antigenic determinants, and topographic distributions of neurofilament proteins in the nervous systems of adult frogs and tadpoles of Xenopus laevis. J Comp Ncurol 273:344-358.

Szaro BG, Gainer H (1988b) Immunocytochemical identification of non-neuronal intermediate filament proteins in the developing Xenopus laevis nervous system. Dev Brain Res 43:207-224.

Szaro BG, Lee V, Gainer H (1989) Spatial and temporal expression of phosphorylated and non-phosphorylated forms of neurofilament proteins in the developing nervous system of Xenopus laevis. Dev Brain Res 48:87-103.

Szaro BG, Grant P, Lee VM-Y, Gainer H (1991a) Inhibition of axonal development after injection of neurofilament antibodies into a Xenopus laevis embryo. J Comp Neurol 308:576-585.

Szaro BG, Pant HC, Way J, Battey J (1991b) Squid low molecular weight neurofilament proteins are a novel class of neurofilament protein. J Biol Chem 266:15035-15041.

Thompson MA, Ziff EB (1989) Structure of the gene encoding peripherin: an NGF-regulated neuronal-specific type III intermediate filament protein. Neuron 2:1043-1053.

Whitnall MH, Keys S, Ben BY, Ozato K, Gainer H (1985) Neurophysin in the ontogeny of the oxytocinergic and vasopressinergic neurons. J Neurosci 5:98-109.

Zoeller T, Lebacq VA, Battey J (1989) Distribution of two distinct messenger ribonucleic acids encoding gastrin-releasing peptide in rat brain. Peptides 10:415-422. 